経 営 史 学

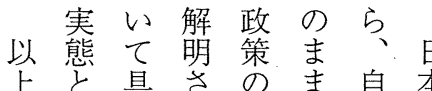
論

上六具さ泍れ立放息本

よ界的た可案置車扮

うをな。・さ忙

な知理ま実れ業る

そる解た施て振自

のこを経のき興動

後々与営状た勾会車

の永充況亡台産

満きい視検い料の

州る壬る点討うに発に

かさの述展

にそられが柋に

関こ宇、実らつ

る な゙思当情れい

研、勝のあいは

究崖授州た满従

基文重。文来

礎い、王々にさ

と 個崖化後满ざ

七 別側只满

は

じ

め

戦 文

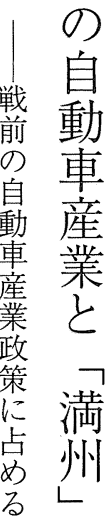

満

州

こ業 満態朗の視

れ. の州は教自角

の

位

置

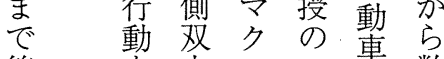

筆方口一蒝数

者通要心連業多

文茵ル研関の

甥当党な゙究公研

車の析日よ事が

産、满本り事

業満本、積

い鏟と州子れ

うに㕍方州歴て

宮

特打閥関に史き

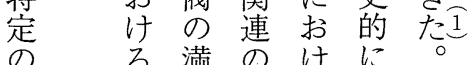

正

業産州もるはし

種業進と経空加

に開出に済白し

絞発にほ統のな

親 
第27巻 第 2 号

額格た国つ可と本担積れ者

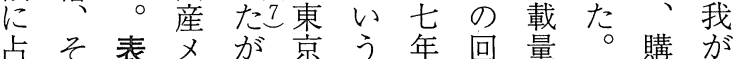
占そ る背に力大斯果同を・体者に 自景み। 戦電を法意五的の拉 動にるは後気も怔味卜に双け 車あよ対の工つ廃しン補方る - るう応軍業た止た以助に自 部生にで縮やこ方も金補動 分産当きや快とれのの額助車 品技時ず不進はるでトをを金産 の術の、況社忘まあうみを業 割と自日のなれでりッた交に 合マ動本などて、、クの付 対 は、車フか軍は軍自おがしす 、ケ供オで用な用動よ表てる 表テ給、そ自ら保車、び，自政 3 イ台ドの動な護工業そで動府 にン数、経車い6自業のあ車の みグに日営補。動そ応るの干 る技占本環助車, れ用。生渉 よ 術め $\mathrm{G}$ 境法自車同産 は うの る $\mathrm{M}$ は の に日輸の悪指 次米入設化定 第の 組 立し 会 に差立にて 社 見は車よいは 過いははつつつ ぜが な て た 実 補 なとき質ま金 いもな的た类

\&し比に三交

の が重国 三付

にたを内年を

なか占市の受

つつめ 場関け

てたるるを東て

生体の表尘、

産の生に利一

を保産も用九

担護と利み学入

し成用よ方年

たををうめの

企意重視欧有、軍 をしし米事用 したな諸の自 て が国際動 大のらのに車 型で、方徴 補 車は平式発助 のな時に方法 技かになるし い。に外大軍術つおらとに っこ至資震用にたけついよ たう系竾保うのるてうり ○したに後護いで軍採意ス こて。明の自てあの用図夕 の 本 製 け 需 動 よ邦品渡, 要 車 う輸のしのの な入品て 堌生 外品質し大産

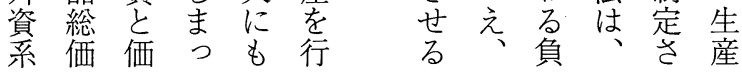
継る 保ささの 承。有れ $れ$ 卜 発とにたとし 展は係同にた さいわ法制

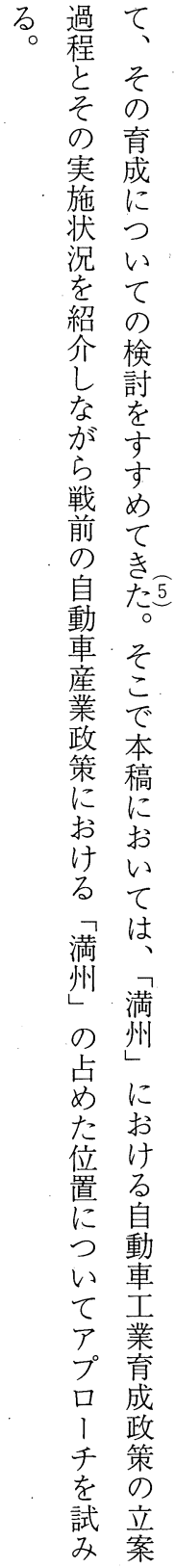


経 営 史 学

表 1 軍用自動車補助法に基づく補助金額

\begin{tabular}{|c|c|c|c|c|c|c|c|}
\hline \multicolumn{3}{|c|}{ 車 } & \multicolumn{2}{|c|}{ 製造補助金 } & \multirow{2}{*}{$\begin{array}{l}\text { 増 加 } \\
\text { 補助金 }\end{array}$} & \multirow{2}{*}{$\begin{array}{l}\text { 購 買 } \\
\text { 補助金 }\end{array}$} & \multirow{2}{*}{$\begin{array}{l}\text { 維 持 } \\
\text { 補助金 }\end{array}$} \\
\hline 規 & 格 & 積 載 量 & 4 輪車 & 6 輪車 & & & \\
\hline$上$ & 甲種 & $3 / 4 \sim 1$ トン未満 & 400円 & 1,400円 & 500円 & 1,000 円 & 400円 \\
\hline $\begin{array}{l}\text { ज } \\
\text { \% }\end{array}$ & 乙種 & 1 1 1/2 トン未満 & 750 & 1,750 & 500 & 1,000 & 500 \\
\hline ク & 丙種 & 11/2トン以上 & 1,250 & 2,200 & 500 & 1,000 & 600 \\
\hline 応 & 丁種 & $3 / 4 \sim 1$ トン未満 & 250 & 1,250 & 375 & 750 & 300 \\
\hline 用 & 戊種 & 1 1 1/2トン未満 & 500 & 1,500 & 375 & 750 & 400 \\
\hline 車 & 已種 & $11 / 2$ トン以上 & 800 & 1,800 & 375 & 750 & 500 \\
\hline
\end{tabular}

（備考）1．製造補助金および増加補助金は製造者に対する補助金で、增加補助金は製造者が直接使 用し: または他人に使用せしめる場合に受ける補助金である。

2. 購買補助金および維持補助金は、一般購買使用者に対する補助金である。

3. 製造補助金および購買補助金は 1 回限り、1 台当りの補助金であり、增加補助金および維 持補助金は、 5 年間を限り下附される1 力年の補助金を示す。

4. 6 輪車は昭和 5 年 3 月から保護自動車に追加されたものである。

（出所）日本自動車工業会編『日本自動車工業史稿』2、1967年、174ページ。

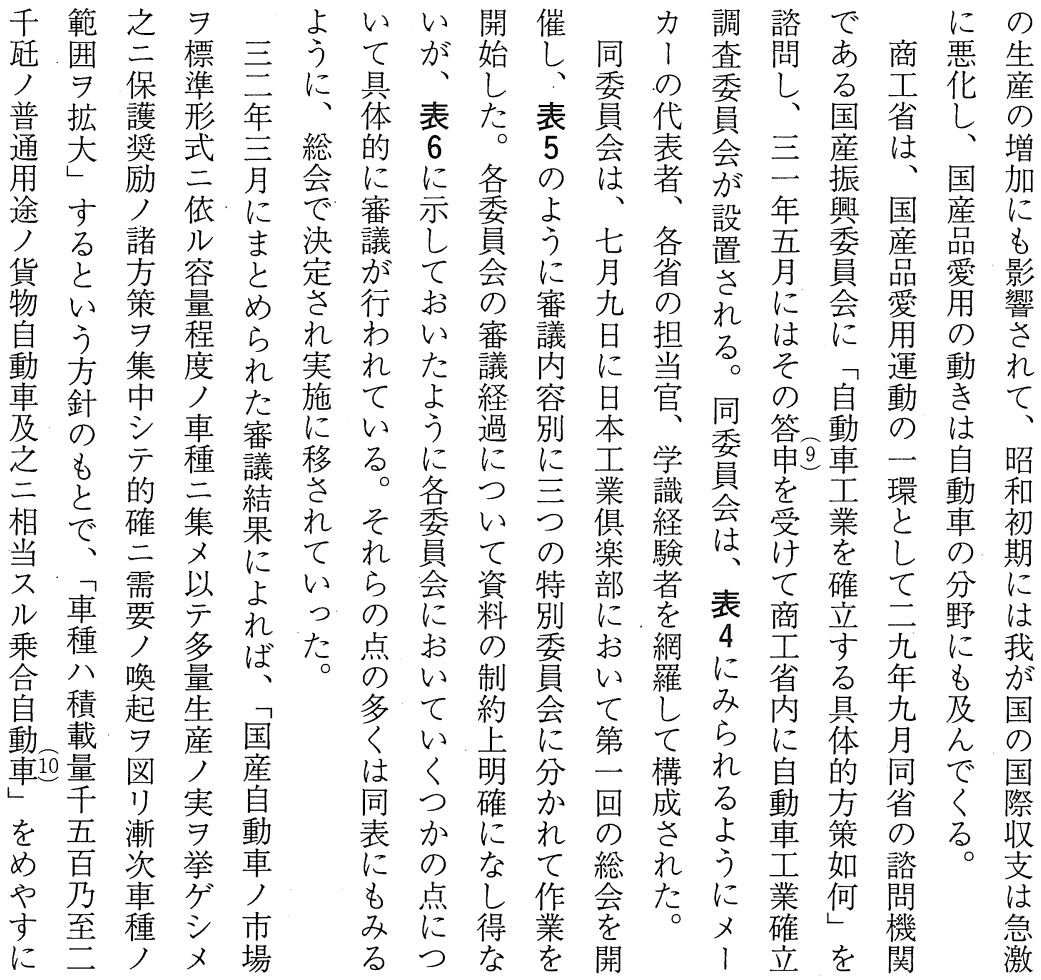


第27巻 第 2 号

表 2 自動車の供給状況

(単位：台)

\begin{tabular}{|c|c|c|c|c|c|c|}
\hline \multirow{2}{*}{ 年 } & \multirow{2}{*}{ 輸入完成車数 } & \multirow{2}{*}{$\begin{array}{l}\text { 国内生産 } \\
\text { （）は小型車 }\end{array}$} & \multirow{2}{*}{ 輸入組立車 } & \multicolumn{3}{|c|}{ 輸入組立車 内訳 } \\
\hline & & & & 日本フォード & 日本 GM & 共立自動車 \\
\hline 1916 & 218 & & & & & \\
\hline 1917 & 860 & & - & & & \\
\hline 1918 & 1,653 & & & & & \\
\hline 1919 & 1,579 & & & & & \\
\hline 1920 & 1,745 & & & & & \\
\hline 1921 & 1,074 & & & & & \\
\hline 1922 & 752 & & & & & \\
\hline 1923 & 1,938 & & & & & \\
\hline 1924 & 4,063 & & & & & \\
\hline 1925 & 1,765 & & 3,437 & 3,437 & & \\
\hline 1926 & 2,381 & 245 & 8,677 & 8,677 & & \\
\hline 1927 & 3,895 & 302 & 12,668 & 7,033 & 5,635 & \\
\hline 1928 & 7,883 & 347 & 24,341 & 8,850 & 15,491 & \\
\hline 1929 & 5,018 & 437 & 29,338 & 10,674 & 15,745 & 1,251 \\
\hline 1930 & 2,591 & 458 & 19,678 & 10,620 & 8,049 & 1,015 \\
\hline 1931 & 1,887 & $436 \quad(2)$ & 20,199 & 11,505 & 7,478 & 1,201 \\
\hline 1932 & 997 & $880 \quad(184)$ & 14,087 & 7,448 & 5,893 & 760 \\
\hline 1933 & 491 & $1,681 \quad(626)$ & 15,082 & 8,156 & 5,942 & 998 \\
\hline 1934 & 896 & $2,247(1,170)$ & 33,458 翰 $\{349$ & 17,244 & 12,322 & 2,574 \\
\hline 1935 & 934 & $5,094(3,913)$ & 30,787 出 $\{26$ & 14,865 & 12,492 & 3,612 \\
\hline
\end{tabular}

(備考) 1. 輸入組立車とその内訳は、資料の関係で台数に相違がある。 2.1916 1925年に至る国内生産台数は不明。

（出所）日産自動車株式会社編『日産自動車三十年史』1965年，16ぺージ。ただし、原資料は、日 本自動車会議所『日本自動車産業ノ変遷卜将来ノ在り方』商工省工務局調查資料。

価が ジを成自電な 生 生税公金る 具 商

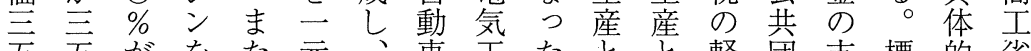
五五がをた元、車王たと軽団支標的省 $\% \%$ 四除同化標製業。販利減体給準な 標 に二年し準造、具売用、、車仕準 実に $\%$ にた車の石体のを関一行に様形 質、の洨○の言的統促税般い対は式 的工百関、生社島に制進のの、し、自 にン仏税自産は自は二し改別使て 表動 引 シ 特も動・国動、元よ 正な用商 7 車 きン 恵改車 販産車三化うにくに教に五

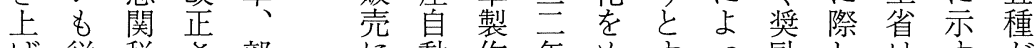
げ従税さ 部動作年めすすつ励しはす 方 ら量でれ分係車所にざるてしてて れ税は、品 わ組、東亦と国、は製お方め たかるる合ダ京こと従こ自官造りら

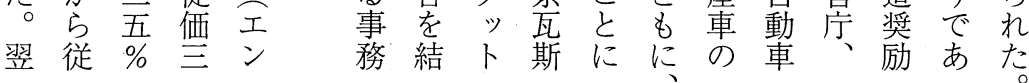


経営史学

表 3 輸入品総価額に占める自動車・部分品の割合

\begin{tabular}{|c|c|c|c|}
\hline \multirow[b]{2}{*}{ 年度 } & 自動車·部分品輸入額 & \multirow{2}{*}{$\begin{array}{l}\text { 本邦輸入品 } \\
\text { 総 価) 額 } \\
\text { (吕) }\end{array}$} & \multirow{2}{*}{$\begin{array}{c}\text { 自動車と } \\
\text { 輸入品総 } \\
\text { 額の歩合 } \\
(\%)\end{array}$} \\
\hline & 合 $\left(\right.$ 円) ${ }^{\text {計 }}$ & & \\
\hline 1922年 & $7,309,835$ & $1,890,308,232$ & 0.38 \\
\hline 1923 & $13,482,280$ & $1,982,230,570$ & 0.73 \\
\hline 1924 & $21,186,123$ & $2,453,402,256$ & 0.86 \\
\hline 1925 & $11,691,442$ & $2,572,657,836$ & 0.46 \\
\hline 1926 & $15,722,201$ & $2,377,484,493$ & 0.66 \\
\hline 1927 & $18,218,971$ & $2,179,152,858$ & 0.84 \\
\hline 1928 & $32,244,823$ & $2,196,314,727$ & 1.47 \\
\hline 1929 & $33,608,383$ & $2,216,420,015$ & 1.50 \\
\hline 1930 & $20,773,730$ & $1,546,070,870$ & 1.30 \\
\hline 1931 & $16,329,163$ & $1,235,675,266$ & 1.32 \\
\hline 1932 & $14,821,423$ & $1,431,461,226$ & 0.98 \\
\hline 1933 & $13,871,350$ & $1,917,219,858$ & 1.38 \\
\hline 1934 & $32,302,224$ & $2,282,532,645$ & 1.40 \\
\hline 1935 & $32,589,347$ & $2,472,236,116$ & 1.31 \\
\hline 1936 & $37,036,025$ & $3,763,681,366$ & 1.34 \\
\hline
\end{tabular}

達 垂 三

さ株 加

れ式 ら

る 会

己 社 標

とを準

に結 車

な 成 の

る、し、製

こ最に

う終は

ᄂ 的 一

てに台

6 三た

に $\vec{\eta}$

み 年 三

た瓦 $\bigcirc$

自 斯 $\bigcirc$

動 電 円

（備考）自動車·部分品輸入額の算定ベースになっている輸入車の台数は、資料 の関係で表 2 の数值とは若干相違がある。

車 \& の

工 合 奖

（出所）日本自動車工業会編『日本自動車産業史』1988年、19ページ。

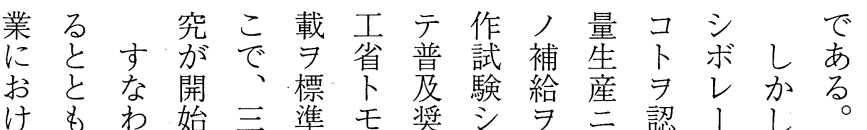

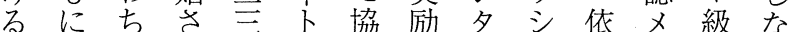

自関軍れ年シ議ノルテリ夕ノが

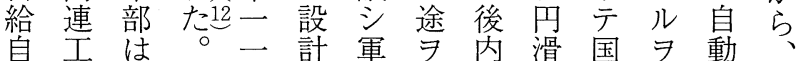

自業は、百計軍講地滑国

体へ自に作於 シ 及ラ工六満

制の動陸

の波車軍実八業州么, 壬站事

整及部施軍確二ル基需輸変

備 効 軍

内久用立於為礎要送

を果事にルト三ケ新確多用

おコス資ル堭立多年験

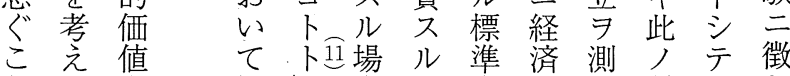

と学標レ合目車車 種概 シ

を準な品的, 草併自六フ

表自分.形つ八

明動認式た一以種種宁莗!

し車識の䣩テ卡 戦ノテド

確 流 励

立 東

調 京 交

査自 付

委 動 さ

䡠 れ

会工る

の業。

決がそ

定設 の

事 立 後

項され 石

着て川

実、島

に生と

の

目販 $卜$

を筅が

み組 合

て 織 同

小 $)$ L

た元自

研そ積 商シ 試 時大ル・化 動 
第27巻 第 2 号

表 4 自動車工業確立調査委員会の構成(1932.3.11現在)

\begin{tabular}{|c|c|c|c|c|}
\hline & 役 & 所 属·役 職 名 & 氏 & 名 \\
\hline (1) & $\begin{array}{l}\text { 委 } \\
\text { 同 } \\
\text { 同 } \\
\text { 同 } \\
\text { 同 } \\
\text { 同 } \\
\text { 同 } \\
\text { 同 } \\
\text { 同 } \\
\text { 同 } \\
\text { 同 } \\
\text { 同 } \\
\text { 同 } \\
\text { 同 } \\
\text { 同 } \\
\text { 同 } \\
\text { 同 } \\
\text { 同 }\end{array}$ & 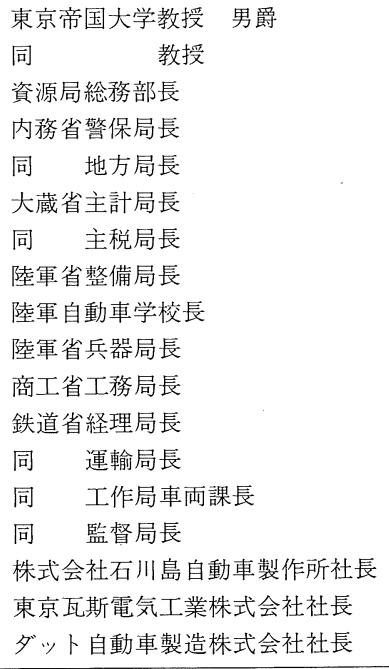 & $\begin{array}{l}\text { 斯 } \\
\text { 波 } \\
\text { 竹 村 } \\
\text { 松 } \text { 井 } \\
\text { 森 岡 } \\
\text { ( 欠 } \\
\text { 藤 井 } \\
\text { 中 島 } \\
\text { 林 } \\
\text { 飯 田 } \\
\text { 植 村 } \\
\text { 竹 内 } \\
\text { 工 藤 } \\
\text { 日 浅 } \\
\text { 朝 倉 } \\
\text { 喜 安 } \\
\text { 渋 沢 } \\
\text { 松 方 } \\
\text { 久保田 }\end{array}$ & $\begin{array}{l}\text { 忠三郎 } \\
\text { 勘 恶 } \\
\text { 春 生 } \\
\text { 二 郎 } \\
\text { 員) } \\
\text { 真 信 } \\
\text { 鉄 平 } \\
\text { 桂 } \\
\text { 恒次郎 } \\
\text { 東 彦 } \\
\text { 可 吉 } \\
\text { 義 男 } \\
\text { 寛 } \\
\text { 希 一 } \\
\text { 健次郎 } \\
\text { 正 雄 } \\
\text { 五 郎 } \\
\text { 権四郎 }\end{array}$ \\
\hline (2) & 臨 時 委 員 & 東京帝国大学助教授 & 隈 部 & 一 雄 \\
\hline (3) & $\begin{array}{l}\text { 幹 } \\
\text { 同 } \\
\text { 同 } \\
\text { 同 } \\
\text { 同 } \\
\text { 同 } \\
\text { 同 } \\
\text { 同 }\end{array}$ & $\begin{array}{l}\text { 内務省警保局警務課長 } \\
\text { 陸軍省整備局動員課長 侯爵 } \\
\text { 同 兵器局銃砲課長 } \\
\text { 商工省工務局工業課長 } \\
\text { 同 嘱託 } \\
\text { 鉄道省経理局購買第一課長 } \\
\text { 同 鉄道技師 } \\
\text { 同 同 }\end{array}$ & $\begin{array}{ll}\text { 宮 } & \text { 野 } \\
\text { 井 } & \text { 上 } \\
\text { 林 } \\
\text { 後 } \\
\text { 藤 } \\
\text { 吉 } \text { 田 } \\
\text { 山 岡 } \\
\text { 小日向 } \\
\text { 島 }\end{array}$ & $\begin{array}{l}\text { 省 三 } \\
\text { 三 郎 } \\
\text { 狷之助 } \\
\text { 保 清 } \\
\text { 永 助 } \\
\text { 祐 章 } \\
\text { 栄次郎 } \\
\text { 秀 雄 }\end{array}$ \\
\hline (4) & $\begin{array}{l}\text { 書 } \\
\text { 同 } \\
\text { 同 }\end{array}$ & $\begin{array}{l}\text { 商工属 } \\
\text { 同 } \\
\text { 商工技手 }\end{array}$ & $\begin{array}{ll}\text { 石 坂 } \\
\text { 清 } \\
\text { 水 } \\
\text { 保 } ⿴ 囗 十 ~\end{array}$ & $\begin{array}{l}\text { 善五郎 } \\
\text { 一 郎 } \\
\text { 健 夫 }\end{array}$ \\
\hline
\end{tabular}

（出所）日本自動車工業会編『日本自動車工業史稿』3、1969年、5 ページ。

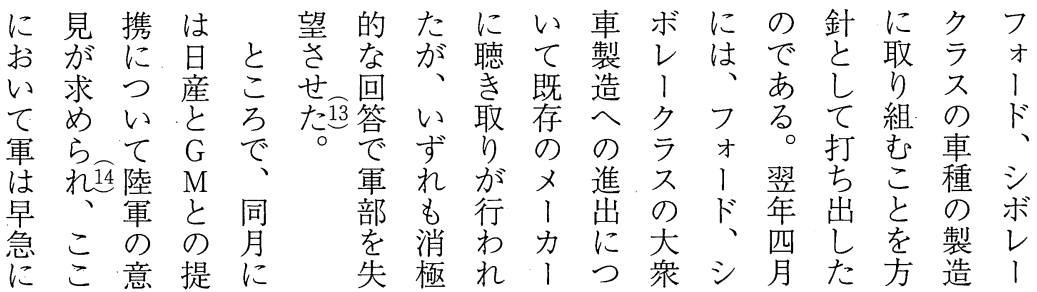


経営史学

表 5 自動車工業確立調查委員会経過概要

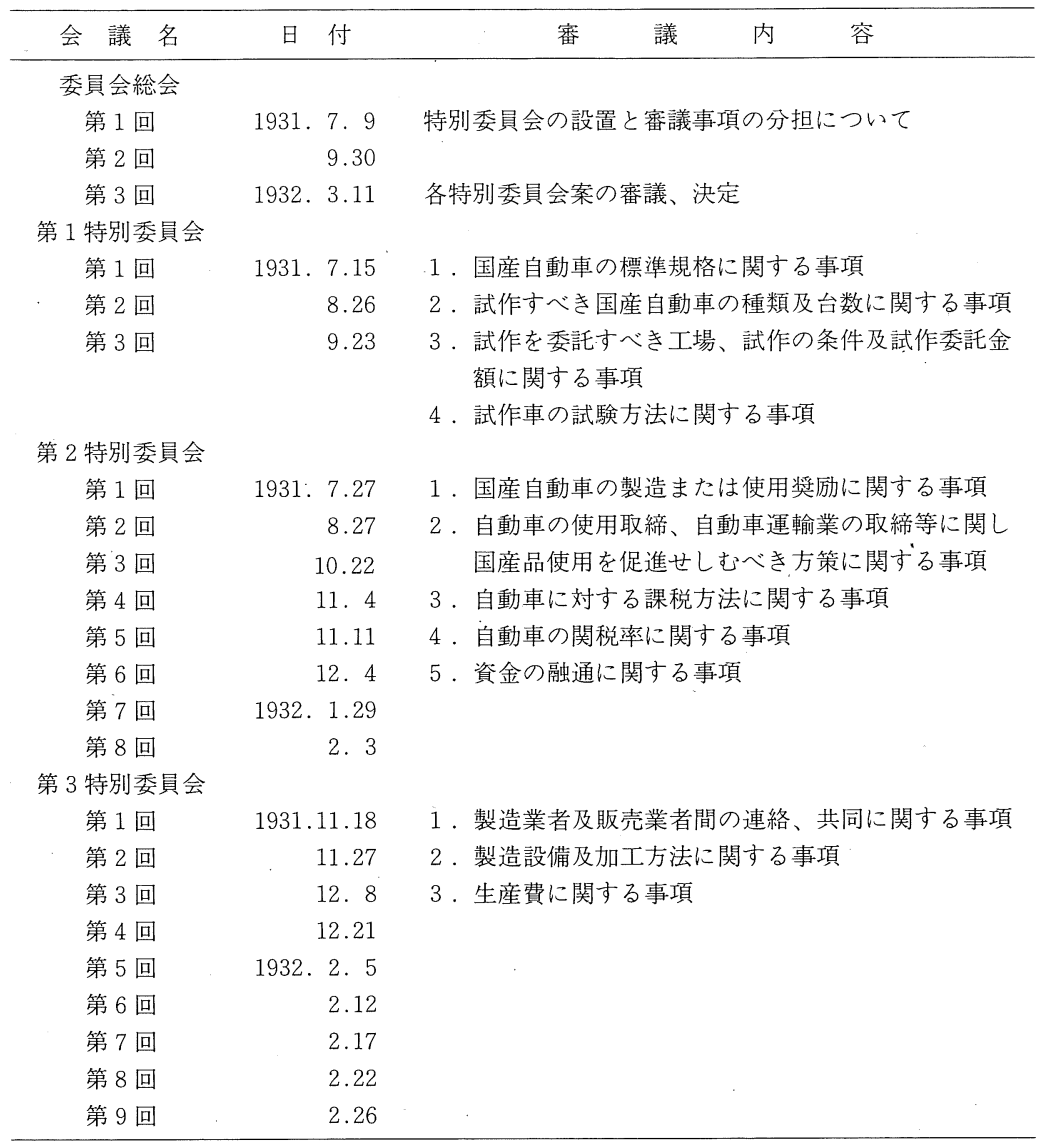

（出所） 商工省工務局『自動車工業確立調查委員会経過概要』1932年 5 月より作成。

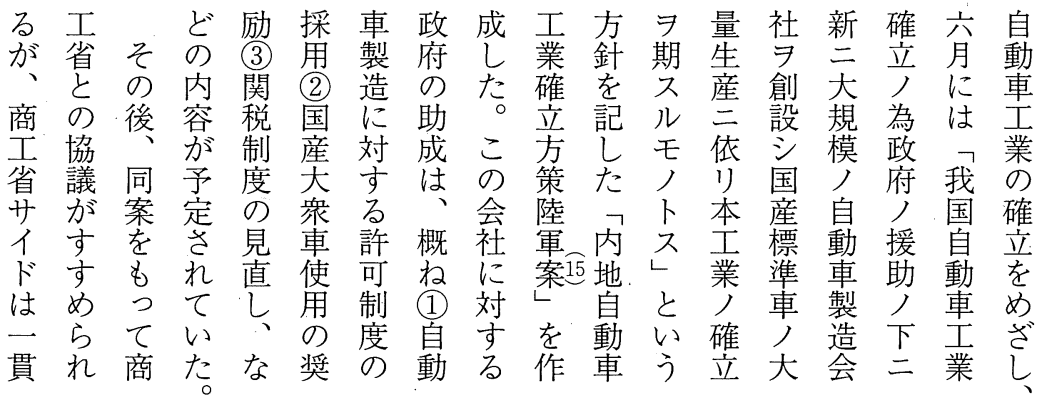


表 6 自動車工業確立調査委員会特別委員会の具体的審議内容と 総会での決定事項

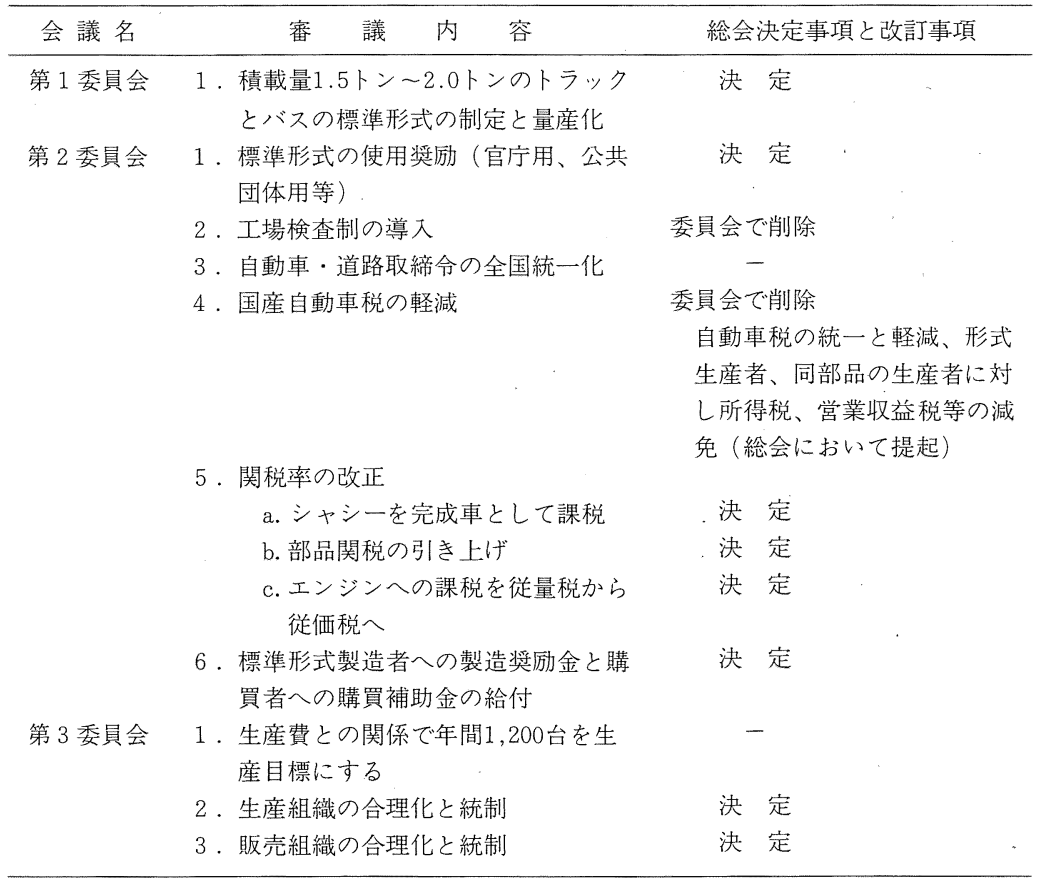

（備考）1.審議内容については主要なもののみ摘記した。 2.一印については、総会で議題にのぼっていない。

（出所）表 5 に同じ。

表 7 商工省標準形式自動車の仕様

\begin{tabular}{|c|c|c|c|c|c|}
\hline 種 & 形式名称 & $\begin{array}{l}\text { 積載量ま } \\
\text { たは定貝 }\end{array}$ & $\begin{array}{l}\text { ホィール } \\
\text { ベース }\end{array}$ & 用 & エンジン仕様 \\
\hline \multirow{2}{*}{ トラック } & TX 35 & 1.5 トン積 & $3.5 \mathrm{~m}$ & 地方一般用 & エンジンはいずれ \\
\hline & TX 40 & 2.0 トン積 & $4.0 \mathrm{~m}$ & 都市 • 近郊用 & 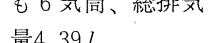 \\
\hline \multirow{3}{*}{ バ } & BX 35 & 23 人乗 & $3.5 \mathrm{~m}$ & 地方一般用 & $45 \mathrm{IP} / 1,500 \mathrm{rpm}$ \\
\hline & BX 40 & 32 人乗 & $4.0 \mathrm{~m}$ & 都市 - 近郊用 & $(90 \times 115 \mathrm{~mm})$ \\
\hline & BX 45 & 40 人乗 & $4.5 \mathrm{~m}$ & 大都市舗装区間用 & X型 \\
\hline
\end{tabular}

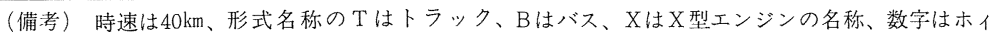
ールベースの長さを示す。バスは低床式フレームに変えた程度で、シャシーとしてはトラッ クとほとんど同一仕様。

（出所）日本自動車工業会編『日本自動車工業史稿』2、1967年、163ページ。 
経 営 史 学

とで鄆そ基こ商体行方商転渉効僚至言しし こあでの的を高制わ条工換統率構た年旦 ろる20ある思省をれ項省で制的想。四産 で。るう同之標整、をとあすに当こ月と

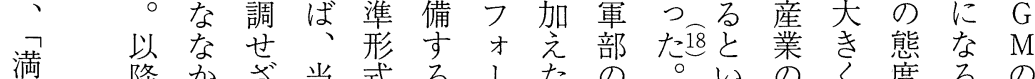
洲降㤎ざ当式る 変同、をの動い、自本方代ず変旦携 社大得日車うシ動方向化か化本を

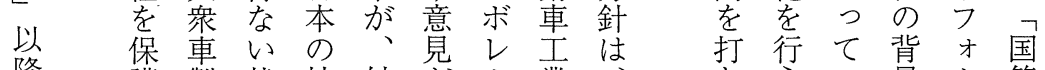
降護製状技外㤎業は、方年景了策 軍守造況術国披ク法こ出とるにド根

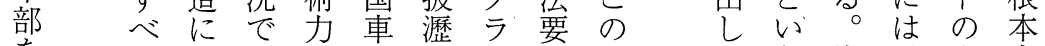

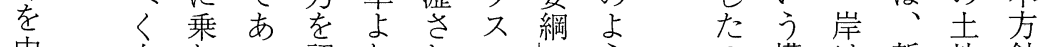
中自りっ認り机の方少構は新地針 心動出た識ひだ至三がな想、想卜 に車しこしと閣 経 急製たとてま議 緯

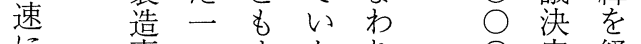
に事つまなり口定経

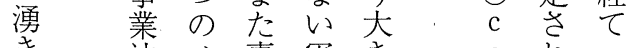

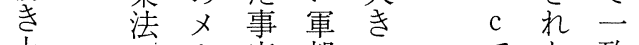

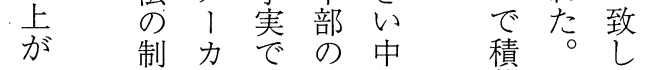
定1 あ独級

たにがっ善車

自動市た的を

車てた結い

産羓本論に

の的量市て

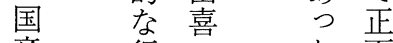

産行一た面

自政郎安

立策率的

をイい辛の

求ドる学

め的豊筝

動俥自々は標定社

と決会

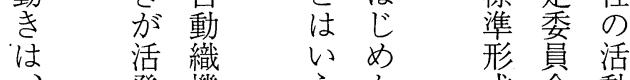

本発機

国乬 作

ほ い自

之方

式会 動

商断指最制

工念定 終限

量 啈 を

あをドく收混

る抱イ工問淆

従て

来い産長表携

のた業、面化

民特理 政 L 华

間に化課、以

の、運長こテ

事自動にこ国

業動を就に策

を車視 任至 樹

援を察しつ立

助はしてて

・国陸促め経た商縫

五産軍進と験岸工

ン動案致名信当人

の車外熏、壬

も形資い要我小陸儿

う産が金軍 カ

政業国義,

府のに照意如

の育も方見キ

方成統い二態

針に制わ共度16

かは経ゆ鳴で

の国を豨儿

大 が導新二正っ

き干管した。 
そ原它を州決担由部調

の案同のれ結的定当かと査

な通案当て論のず案部ら密・満

かりは時いし 市亥に局産接立州

で可七とた、場三焦に業に案し

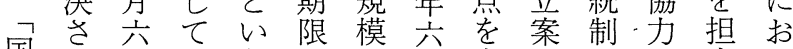

国机白はう付や，月当ががし当い

内た23開む状き部に艺行求なして

需。催し況な品尘なわめがたは

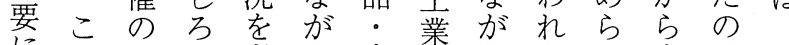

に垫経現考占素班占たれ妾は満

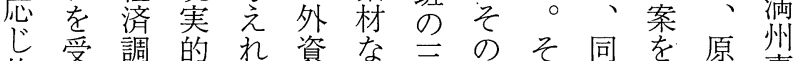

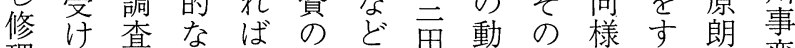

理取委結、進の屵き経の孝教変

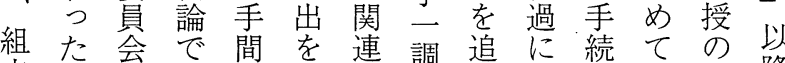

立特会あの許蒫調势うきい研降

る務審っ吕容業貣さいでる。究統

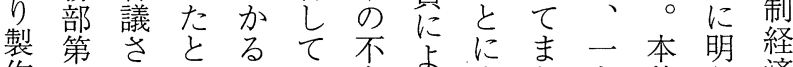

作四和国い在り方尔稿ら済

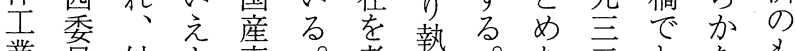

業員外卓。考筆。た三となも

に会出資うの当慮害年年り年

漸はに。育時しれ、が四あうで

進、対成、てた

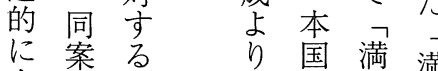

企老制 も州州

業 参 限

せ著を

せ考㖈 䯩場に於

る - 完 質 日て る

々月全価本自動

と自自格フ動車

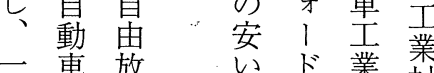

二車放外 ゙、業就

月業に星早興策

日策るに $\mathrm{G}$ のに

の案唱任 $\mathrm{M}$ は

特決染の不掠

務をした製可し

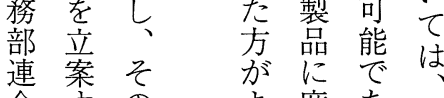

合守の る

年月げに日

表 ! る 満本

1 三自鉄の

で亥動経帝

あ年車済国

る一王調主

一業查義

以月妄会経

下に成莒

立たにっす

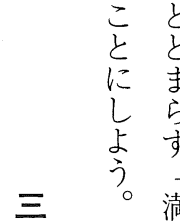

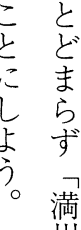

満学

に包

お方

け 加

自た た

動息

車進

業放

充

成政次

策

そ

満

州

系てい。

過経て 経ら

程済も済れ

の

動

で調産調る

登查業查が

場 会 開 会

す第、発は経

る二や、済

い部軍関 統

<工事東制

業上軍 政

か班の特策

のを理務の

き
に
い
$\tau$
み
$\tau$
$w$
$<$ 
経営史 学

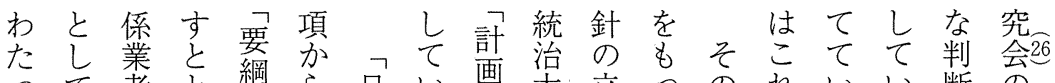

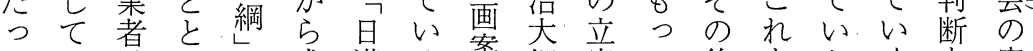
ては及是も成満る案綱案て後をたくを審 い、満に五り、自よを案作浮自ものこ下議 る部鉄、五、動う基業上動つでと方で 。品を修点自車に基か璴莗てはに経は ま関主理 り動会判礎ら、て 立 立なな 済外

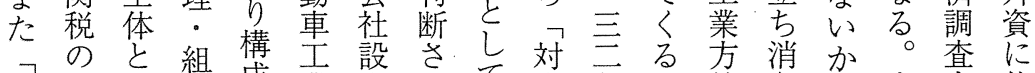

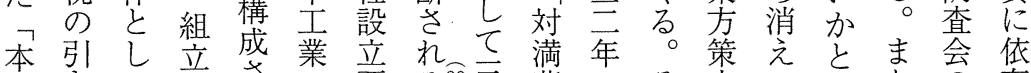

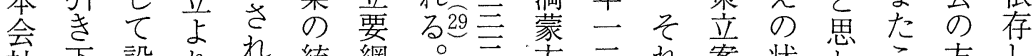
社下設り华統綱。文方三系案状わこ方し にげ立製本制し年策居にへ態れのの針な

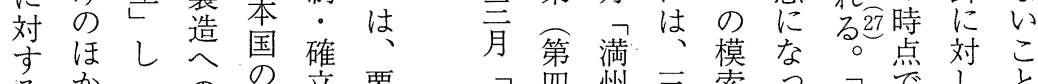

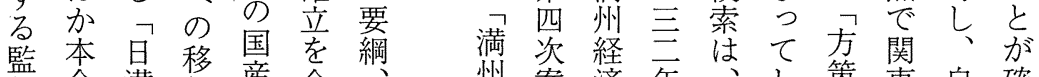
督会満行産企社州案済年合し策東自確

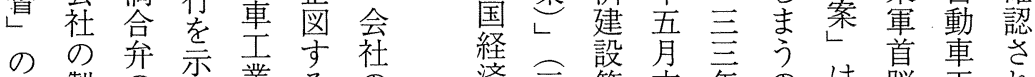
項製の唆業る の 済三第末末年のは弾王れ

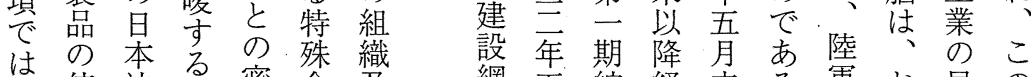
は、使法も密会及織綱五綜経立る 葷お早の 角人の接社び 要合済案。省々期時

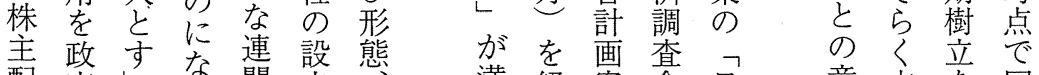
配府しな関立当満経案会日意本を国 当、るて州会公側満見国標産 は満旨いも運社国模とに自調の榜自

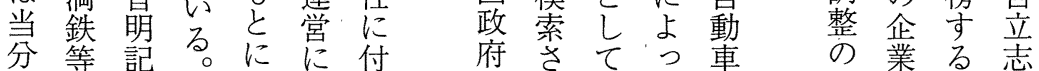

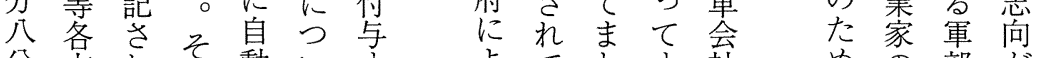

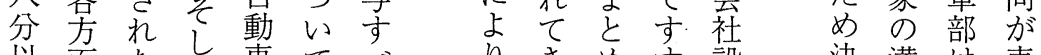
以面た艺車て 今゙きめ主設 決満は表 内に公た らめ立定州そ奛 と指以本業体便表関れら要和進のさ

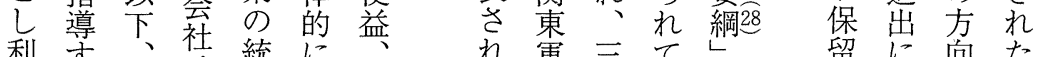

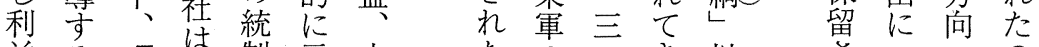

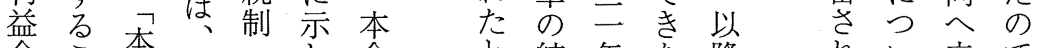
金己本 会し会統年た降的立で のと会全確た社い制一経きき航 案あ 処、社般立最に方理 ○済わ初対楽のる 分な 付的を初対 統

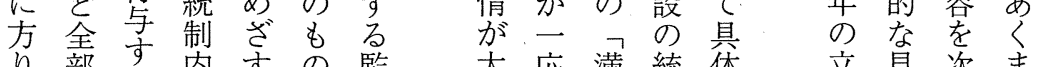
り部息内亦の監 大応満統体 立見次ま はできに方で督导熟蒙制的 案通第で

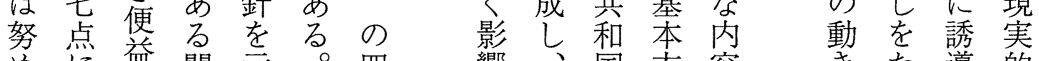
めに焦関示。四、響、国方容きた 導的 
年表 $1 「$ 日満自動車会社設立要綱案」の立案過程

\begin{tabular}{|c|c|}
\hline \multirow{2}{*}{\multicolumn{2}{|c|}{ 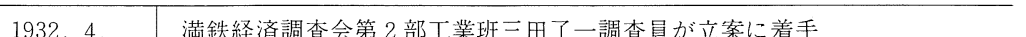 }} \\
\hline & 満鉄経済調査会第 2 部工業班三田了一調査員が立案に着手 \\
\hline 6. & 「满州に於ける自動車工業対策案」(三田) \\
\hline 7. 6 & 「同上」に関する経済調査会委員会、「同上」決定 \\
\hline 11.19 & 「自動車工業方策案」（関東軍特務部第 4 委員会） \\
\hline 12. 1 & 特務部連合研究会に於て「同上」につき審議、一部修正 \\
\hline 12.19 & 特務部連合委員会に於て「同上」修正案につき審議、保留 \\
\hline 1933. 5.5 & 「日満自動車会社設立要綱」(満蒙委員会) \\
\hline 7. & 「満蒙委員会提唱日満自動車会社設立に関する対策」（第 3 部道路班） \\
\hline 10. & 「日満自動車会社設立要綱案」（関東軍特務部） \\
\hline 10.12 & 「同上」に関する特務部連合研究会 \\
\hline 10. & $\ulcorner$ 同上」に対する対策 $(3$ 案より 構成 $)\ulcorner$ 自動車工業対策要綱案」（経調第 2 部 \\
\hline 10.27 & 「自動車工業対策要綱案」に関する経調委員会、第 1 案を修正可決 \\
\hline 10.28 & 「同上」修正案を関東軍特務部に通皤 \\
\hline 11. 1 & 「日満自動車会社設立要綱案」に関する特務部連合委員会 決定 \\
\hline 11.11 & $「$ 同上」関東軍司令部にて採用決定 \\
\hline 11.14 & 関東軍参謀長小磯国昭より満鉄経済調査会委員長十河信二宛 \\
\hline
\end{tabular}

（出所）満鉄経済調查会『満州自動車工業方策』（立案調査書類第 6 編第 4 巻）1935年、その他より 作成。

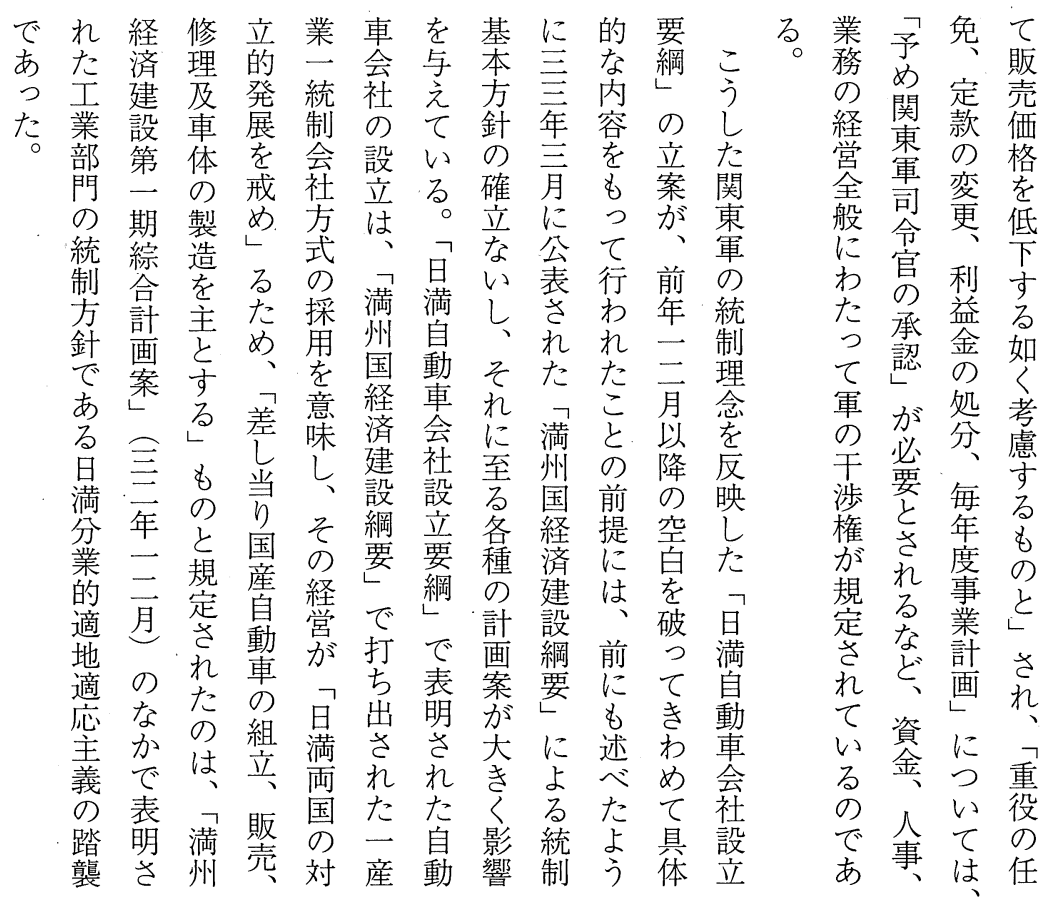


経 営 史 学

資響 現実—とが業可路組が立しら会に

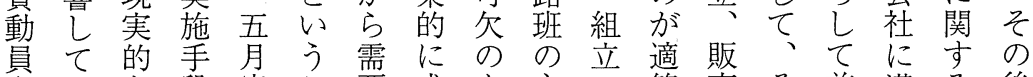
をいな段案こ要成も主・策筧そ首満る後

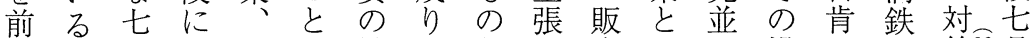

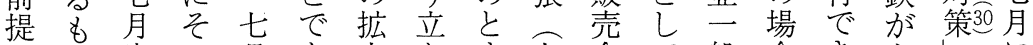
にの案の月あ大た市芸て般合き主にに しとで相案つになる月社い車市ず体をな た思な違とた従いそ案のる輛同、に稿つ 軍わくがも。うと設。の社満な了て

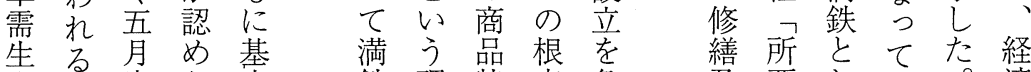
産。案ら本鉄理特底急紧要し参。済 力散れ的 の由性に尘車のて加そ調 の満採るな有でよは五 体自は守れ查 拡州用。狙, 寸可㗢速る

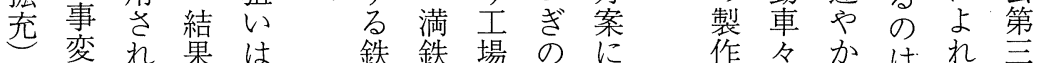

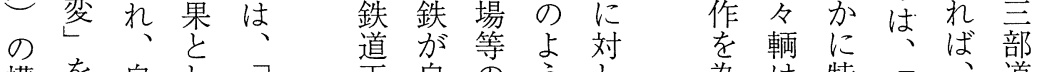

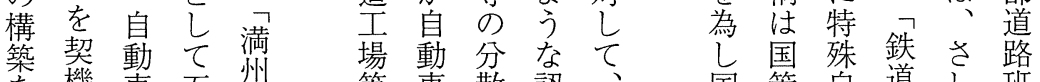
を機車五州等車散認、国策自道し 班 めと王月にで運配識七産上動のああ ざし業案に組輸置が月自可車経た

すてのを怙立会があ案動及連嫦り交

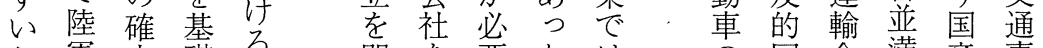
わ軍立、礎国、開を要た は间侌満産事 ゆ内学竞始設文。運普産社蒙車業 るに軍、産立なす輸是品を仙の対

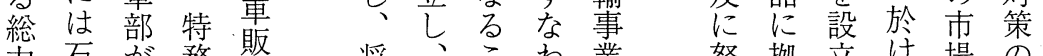
为名務路将、こわ業努拠立け場の 戦原急部路 来積と ち統 めるる し る 開 観 思莞いは拡組極少需制 以事、産拓点

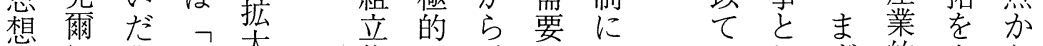

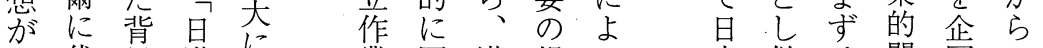
台代景満基業国満規る 本併は開図 頭表に自基学産州模国国せ交発し満

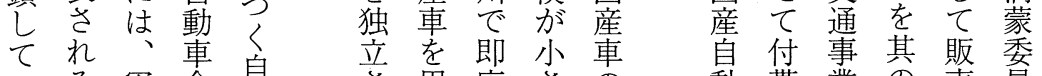

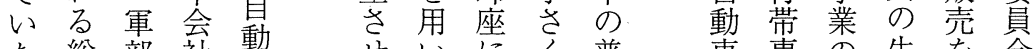
た総部社動 せいにく普車事の生を会 の力の設車るて 組、是 虽統命中提 で戦 総立業方販立ア が業と制と心唱

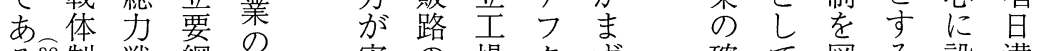
る32制戦綱早実の場夕夺確て図る設満

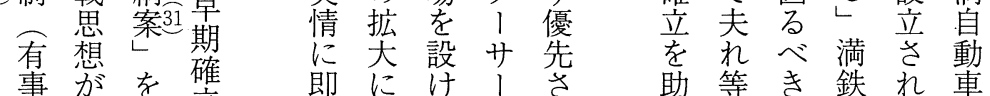
の大事 立立 即に協る 際き案を゙少の不た輌あ使自社

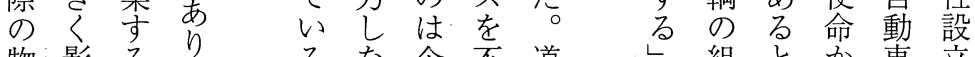
物影るるる企不道組と市立 
第27巻 第 2 号

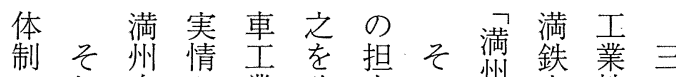

のれ自や業改当の州半株三 確に動只方組光経の額式年

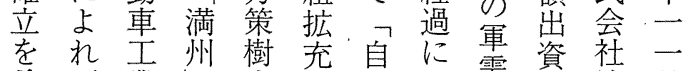
希ば業州樹充息に需資社 望、拡の小て車い業がをに 軍充自委到王て羓誕制 る部方動筫達業み垫生定日 との策38車会守方た充しし満 の 満上工去る策の文、自

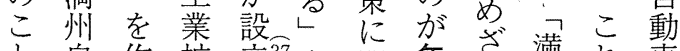

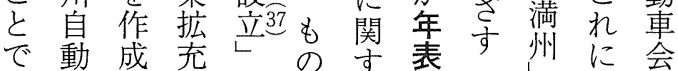
あ車し方さと方2旁に基社 る严た策热し議で産に基設

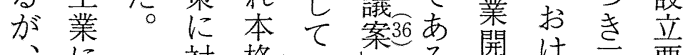
絰対対格い年発主要 合等方的るが最䇤自年案 機る軍方四成初置動严法 械意部策四盛に許車量は 工 見 業 と でし る.

自 少 動 な 車 業

の 軍 特 用 異 特 性、殊

採 動

算 車

性 に

本 w

国 て

メは

l早

力 急

l急

の自

生 給

産 自

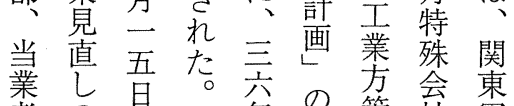
意業へで○環体和決 竟鼻ば息現息定 等 ス動は、の元憅 案 を多車満自て車と 考占踾箇鉄動々業て 慮々羓箇職車こ䍩て た策計制䟿と式式 調。樹画改羓に会に 查同立実正部な社採 報委の現に用 告䆩為の方た算さ 会め大り策。本れ 澘虽済要設策そ金た の本調同真䚁後立そ 自国查和机直方 動の委をた省方方 車自貣中産行年円 工動会心業行に、同 業車基部わな満和 実産に基商れるる州自 情業自と高たと、国動 と動し課35 者のにそ年—策社軍 の作等こ二環を同の
の同 体

浞は案を要

案而関綱

四

な月東案

こ二軍は

満少昌官針

州只務かと

あ部らて

にる連满は

お。合洲五

け石州月

る 究画案

息会府何

動席に変

業協書恋

業・議換る

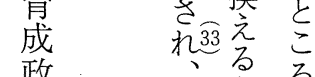

策再な゙は

の度ど見

実字若 当

上吕ら

修字な

辞句

上尗た

修修設

正步 $\frac{\text { 立 }}{\text { 品 }}$

施行方

れれたぎ

最に社

終要の

的导援

にな助

は兄

れそ監

がの

軍後主 
経 営 史 学

年表 2 自動車工業拡充方策要綱案」の立案過程

\begin{tabular}{|c|c|}
\hline 1937.3. & 「自動車工業方策に関する議案」（満鉄産業部商工課）作成 \\
\hline 4. & 満鉄経済調查委員会内に自動車工業方策樹立小委員会設立 \\
\hline 4. & $\begin{array}{l}\text { 満鉄産業部商工課「満州に於ける自動車拡充計画と同和の現状」 } \\
\text { 「同和自動車会社の拡充五箇年計画案」を小委員会に参考のため提出 }\end{array}$ \\
\hline 8. & $\begin{array}{l}\text { 自動車工業方策樹立小委員会は調査報告書「日本の自動車工業実情と満州自 } \\
\text { 動車工業拡允方策」を作成 }\end{array}$ \\
\hline 8. & $\begin{array}{l}\text { これに基づき「自動車工業拡立方策要綱案(五箇年計画)」を立案 } \\
\text { 経済調査委員会に於て「同上」につき番議 }\end{array}$ \\
\hline 9. & $\begin{array}{l}「 \text { 自動車工業拡无方策要綱案(五箇年計画) (改訂)」(自動車工業方策樹立小 } \\
\text { 委員会) 作成、経済調査委員会に於て決定案として採用 } \\
\text { 関東軍宛決定の旨通牌 }\end{array}$ \\
\hline
\end{tabular}

(出所) 満鉄調查部『自動車工業関係資料』1937年より作成。

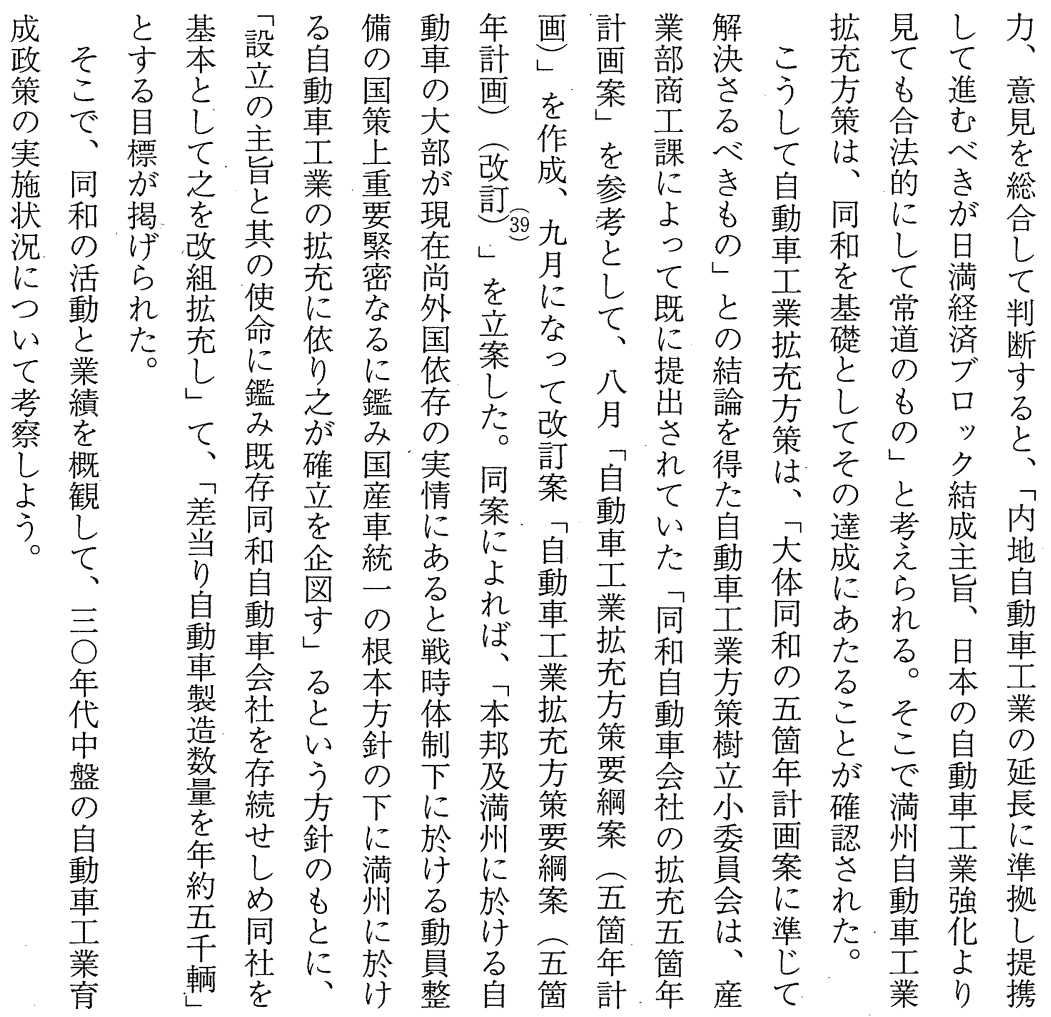




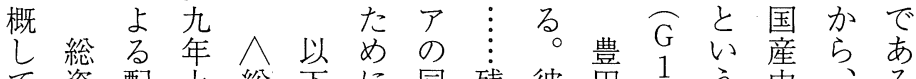

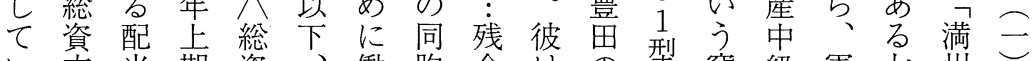
心本当期資、働胞念はの型窮級軍七州

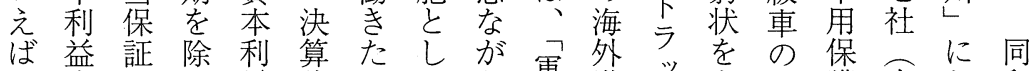

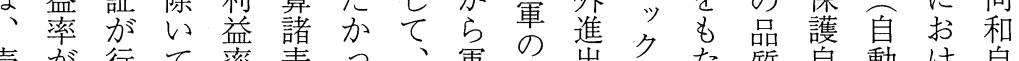
売㤎行て 率表つ、軍い出之た質自動け自

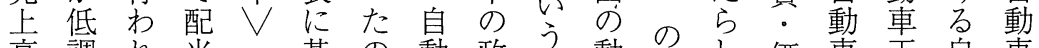
高調 れ 当基の動政 、動 $\mathrm{K}$ ᄂ 価車亚自車 利なて 率 総づで車策い機 $\mathrm{K}$ た 率因たも本てる的場、わゆし輸そ面商東工株 もと加満利財டの市ゆて組のの省京業式 低しらな益務と開場るは組後劣標瓦の会 くてでな率的述発育尘、立勢準斯 確社

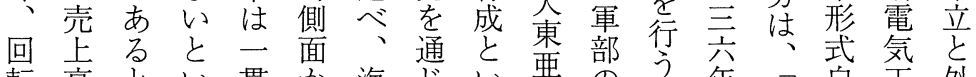

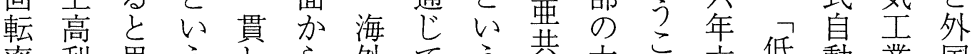

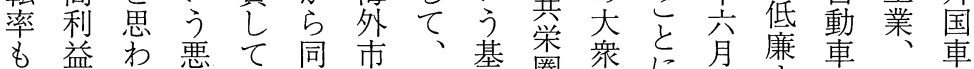

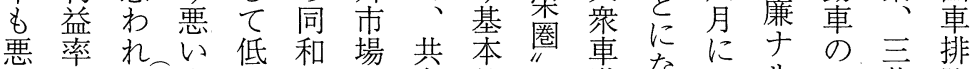

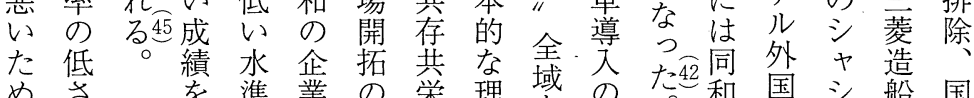

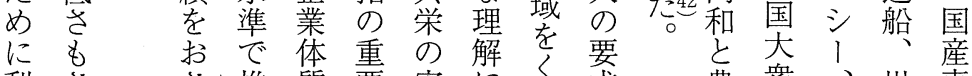
利さ推質要実に求豊衆、、川車

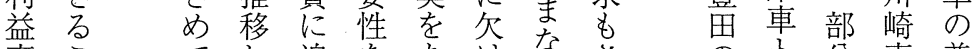
率こてし迫をあけななな子小分車普

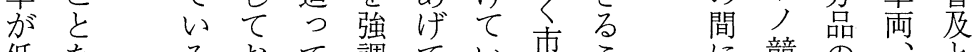

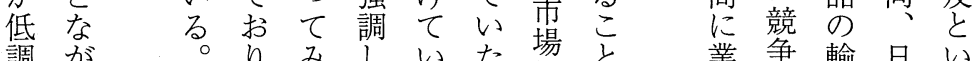

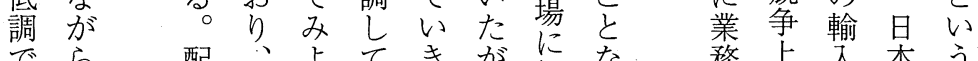
でら、配、よてき尔網な務上入本う あ、当自ういた、網が提殆組車重

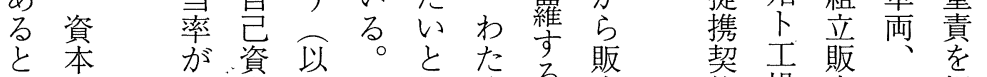
判回 叴資 市 断転 \% 利、号し必要部㤎原を畑つ さ率に益表 た自要長成価 鋳て れの 固率 8 身古神立 7 夕物活 る極定もに微は方谷信 以 、動 端さ导依 同る 正

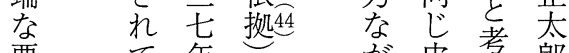
悪て 年法皮考郎

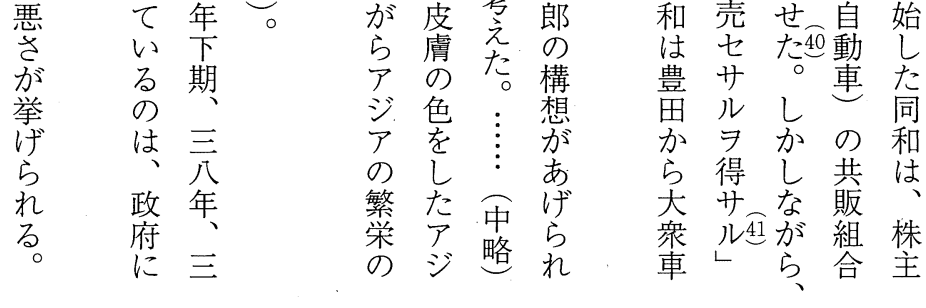


表 8 同和自動車工業 財務分析表

\begin{tabular}{|c|c|c|c|c|c|c|c|c|c|}
\hline $\begin{array}{c}\text { 各期決算 } \\
\text { 年·月 }\end{array}$ & $\begin{array}{c}\text { 第 } 1 \text { 回 } \\
1937 \cdot 6\end{array}$ & $\begin{array}{r}\text { 第 } 2 \text { 回 } \\
\cdot 12\end{array}$ & $\begin{array}{c}\text { 第 } 3 \text { 回 } \\
1938 \cdot 12\end{array}$ & $\begin{array}{c}\text { 第 } 4 \text { 回 } \\
1939 \cdot 6\end{array}$ & $\begin{array}{r}\text { 第 } 5 \text { 回 } \\
\cdot 12\end{array}$ & $\begin{array}{c}\text { 第 } 6 \text { 回 } \\
1940 \cdot 6\end{array}$ & $\begin{array}{r}\text { 第 } 7 \text { 回 } \\
\cdot 12\end{array}$ & $\begin{array}{c}\text { 第 } 8 \text { 回 } \\
1941 \cdot 6\end{array}$ & $\begin{array}{r}\text { 第 } 9 \text { 回 } \\
\cdot 12\end{array}$ \\
\hline $\begin{array}{r}\text { (円) } \\
\text { 売上高 }\end{array}$ & $5,050,933$ & $7,460,193$ & $23,901,052$ & $11,938,197$ & $26,440,680$ & $32,554,241$ & $28,768,594$ & $?$ & $33,803,337$ \\
\hline 売上原価 & $4,249,929$ & $6,434,384$ & $21,129,325$ & $10,199,023$ & $21,358,744$ & $26,844,218$ & $23,336,588$ & $?$ & $28,564,817$ \\
\hline 営 業費 & 554,195 & 537,663 & $2,078,525$ & 362,964 & 749,702 & $2,185,915$ & $1,124,375$ & $?$ & 873,891 \\
\hline 財務費用 & - & - & - & $1,127,146$ & $3,660,508$ & $3,086,867$ & $3,547,369$ & $?$ & $5,053,852$ \\
\hline 流動資産 & $3,733,142$ & $7,844,108$ & $18,318,742$ & $26,760,259$ & $57,195,419$ & $65,598,336$ & $71,921,439$ & $76,590,528$ & $67,198,918$ \\
\hline 固定資産 & $1,148,675$ & $1,724,835$ & $2,878,328$ & $4,531,277$ & $9,648,274$ & $13,055,601$ & $16,888,238$ & $18,638,508$ & $22,464,619$ \\
\hline 流動負債 & $2,146,579$ & $5,144,400$ & $4,457,216$ & $23,834,675$ & $14,419,778$ & $11,893,796$ & $17,848,847$ & $37,379,751$ & $18,651,697$ \\
\hline 固定負債 & - & $1,000,000$ & $9,520,000$ & 322,798 & $32,578,220$ & $34,253,160$ & $38,125,593$ & $24,800,000$ & $38,179,616$ \\
\hline 総資 本 & $8,555,256$ & $13,033,705$ & $21,197,070$ & $31,291,536$ & $78,779,694$ & $78,653,937$ & $88,809,678$ & $95,229,036$ & $89,672,537$ \\
\hline 自己資本 & $3,617,413$ & $4,039,853$ & $7,038,853$ & $7,134,063$ & $19,881,696$ & $32,506,981$ & $32,835,238$ & $32,084,238$ & $32,814,223$ \\
\hline $\begin{array}{r}\text { 当期利益 } \\
(\%)\end{array}$ & 208,677 & 689,305 & 741,310 & 433,237 & $1,068,633$ & $1,339,785$ & $1,201,430$ & 965,048 & 955,938 \\
\hline $\begin{array}{l}\text { 総資本 } \\
\text { 利 益率 }\end{array}$ & 2.44 & 5.29 & 3.50 & 1.39 & 1.36 & 1.70 & 1.35 & 1.01 & 1.07 \\
\hline $\begin{array}{l}\text { 総資本 } \\
\text { 回転率 }\end{array}$ & 0.59回 & 0.57 回 & 1.13回 & 0.38 回 & 0.33 回 & 0.41 回 & 0.32回 & $?$ & 0.38 回 \\
\hline $\begin{array}{l}\text { 売 上高 } \\
\text { 利益率 }\end{array}$ & 4.13 & 9.24 & 3.10 & 3.63 & 4.04 & 4.12 & 4.18 & ? & 2.83 \\
\hline $\begin{array}{l}\text { 売上高対 } \\
\text { 売上原価 }\end{array}$ & 84.14 & 86.25 & 88.40 & 85.43 & 80.78 & 82.46 & 81.12 & $?$ & 84.50 \\
\hline $\begin{array}{l}\text { 売上高 } \\
\text { 対営業費 }\end{array}$ & 10.97 & 7.21 & 8.69 & 3.04 & 2.84 & 6.72 & 3.91 & $?$ & 2.59 \\
\hline $\begin{array}{l}\text { 売上高対 } \\
\text { 財務費用 }\end{array}$ & - & - - & - & 9.44 & 13.84 & 9.48 & 12.33 & $?$ & 14.95 \\
\hline 固定比率 & 31.75 & 42.70 & 40.89 & 63.52 & 48.53 & 40.16 & 51.43 & 58.09 & 68.46 \\
\hline 負債比率 & 59.34 & 152.09 & 198.57 & 338.62 & 236.39 & 141.96 & 170.47 & 193.80 & 173.19 \\
\hline 流動比率 & 173.91 & 152.48 & 298.81 & 112.27 & 396.65 & 551.53 & 402.95 & 204.90 & 360.28 \\
\hline $\begin{array}{l}\text { 自己資本 } \\
\text { 利益率 }\end{array}$ & 5.77 & 17.06 & 10.53 & 6.07 & 5.37 & 4.12 & 3.66 & 3.01 & 2.91 \\
\hline 配 当率 & 6.0 & 6.0 & 6.0 & 6.0 & 6.0 & 6.0. & 6.0 & 6.0 & 6.0 \\
\hline
\end{tabular}

(備考) 1. 数值は全て四捨五入したもの。

2. 副次的収入は金額が過少のため割愛したが、営業費、財務費用については、副次的費用と 分割できないため便宜上本来的費用として一括して計算した（定款によれば、同和の営業 目的は 1 . 自動車の組立 2 . 自動車の製造 3 . 自動車の修理 4 . 自動車の売買 5. 実業部大臣の認可を受けたる前各号に付帯する事項の 5 項である。このうち 1 むに 関するものを本来的、5について副次的として区分した）。

3.ストック関係の比率は、全て期末の額で計算した。

4.? 印については、不明である。

5. 1934年 3 月創業時〜36年に至る資料を欠くので便宜的に37年 6 月期を第 1 回とした。

(出所)「同和自動車工業株式会社概況」昭和13年 1 月、満鉄東京支社業務課「(満鉄ヨリ満業へ)株式譲 渡会社概況」(『満業重要書類』鮎川家所蔵、其一の15)、満州重工業開発株式会社「営業報告. 書」第 2 回〜第 9 回より計算のう之作成。 
第27巻 第 2 号

表 9 同和自動車工業の棚卸資産額の推移（単位：円、\%)

\begin{tabular}{|c|c|c|c|c|c|c|c|c|c|}
\hline $\begin{array}{l}\text { 各期決算 } \\
\text { 年 月 }\end{array}$ & $\begin{array}{c}\text { 第 } 1 \text { 回 } \\
1937 \cdot 6\end{array}$ & $\begin{array}{r}\text { 第 } 2 \text { 回 } \\
\cdot 12\end{array}$ & $\begin{array}{c}\text { 第3 回 } \\
1938 \cdot 12\end{array}$ & $\begin{array}{c}\text { 第 } 4 \text { 回 } \\
1939 \cdot 6\end{array}$ & $\begin{array}{r}\text { 第 } 5 \text { 回 } \\
\cdot 12\end{array}$ & $\begin{array}{c}\text { 第 } 6 \text { 回 } \\
1940 \cdot 6\end{array}$ & $\begin{array}{r}\text { 第 } 7 \text { 回 } \\
\cdot 12\end{array}$ & $\begin{array}{c}\text { 第 } 8 \text { 回 } \\
1941 \cdot 6\end{array}$ & $\begin{array}{r}\text { 第 } 9 \text { 回 } \\
\cdot 12\end{array}$ \\
\hline $\begin{array}{lr}\text { 棚 } & \text { 卸 } \\
\text { 資膺額 }\end{array}$ & $2,120,804$ & $5,252,055$ & $13,168,641$ & $19,131,712$ & $42,091,610$ & $51,164,375$ & $53,877,303$ & $58,323,305$ & $52,531,673$ \\
\hline $\begin{array}{l}\text { 棚 卸 } \\
\text { 流動資産 }\end{array}$ & 56.81 & 66.96 & 71.88 & 71.49 & 73.59 & 77.80 & 74.91 & 76.15 & 78.17 \\
\hline
\end{tabular}

(備考) 円位未満四捨五入。

(出所) 表 8 に同じ。

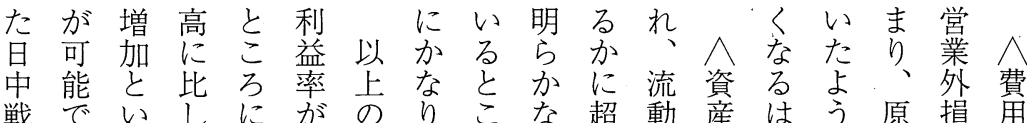

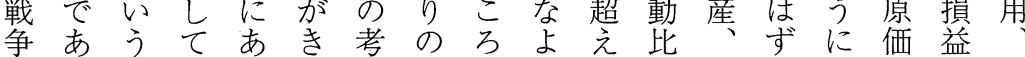
のろ点利るわ察程にうて率負で営が率収 軍うか益。めか度あにおも債市業高と益

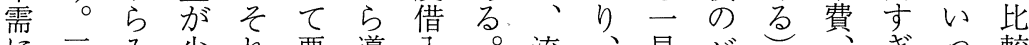
に三み少れ悪導入。流、見バ 。空ぎつ較

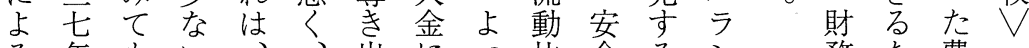
る年もい、、出につ比全るン゙務た費

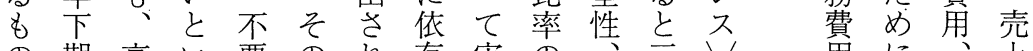
の期高い要 の的存実の主 $V$ 角に卡 でと価うの原るし際高支七に利収高 あ三格こ資因企てののい払年固つ益益利 る年八分産と業い支原能上定い率の益 年高に驾し体る払因力卡比て が対率 が原な多て 質体能はと期率、は低比の 例価るすはを質力流も副か検低

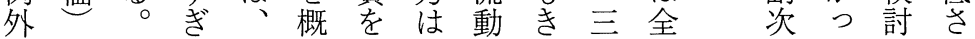
的とすて資括負き資わ无体的たをの にそな且本守債わ産め年的 費と行原 利れわつ回れ比めにて上に角考う因 益にち所転ば率て占良期二 分えとを 率よ嫦有率つ卆不め好の 0 をら がる業資、ぎ示良るの主 $\bigcirc$ 含れ原る 高売成産売のしで棚よ期％兄る価た

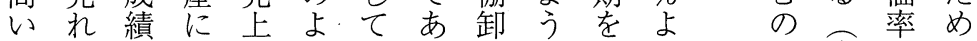
の行低対高ういり資に、除りりで表のに はき調す利にる、産みいか、 8 高売

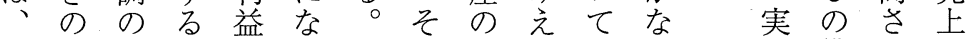
三悪原売率ろ れ割るすすり。際備が原 七学因上のう省合がべ低省考注価 年にはの双。吕法、てい原 2 目率

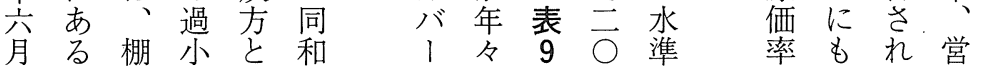

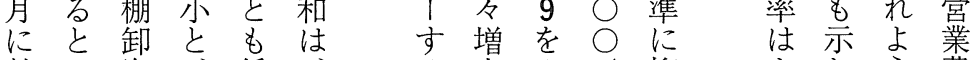

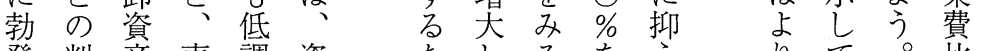

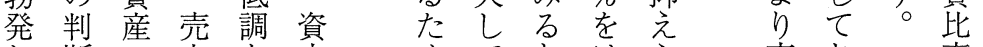

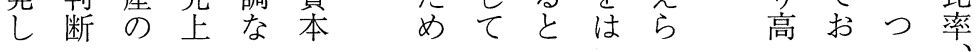


経 営 史 学

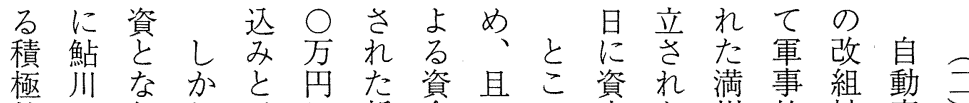
的のりし予に新金つろ本た州的拡車 な構外な定よ設投資で金と重な充工 姿想資がしり自市金、业心重現を業満 勢の の らて 充動も不原億う業地基部州 に二導二小当一車さ足朗円経開調礎門自 表翼入三た菂さ製るに全緯発并にに動 れをはも的造こ絁宇額加加主果掉 た形な年る会とむ田满ら、義たけ製 が药成し は社な関川業、従的さる 造

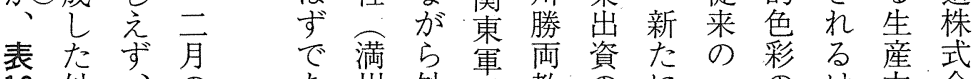
10 外、の州外草教のに一のは力会 に国鮎パり自資洪授満満業濃ず拡社 み技川六動の満の州業二いで充 る術の! 車導州研自傘社もあは、

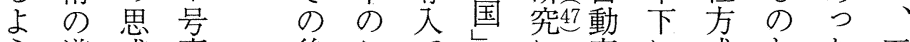

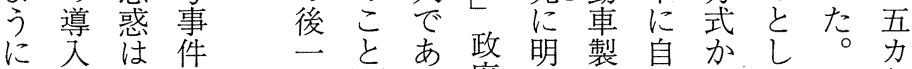

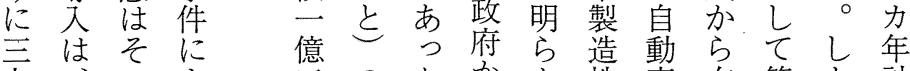

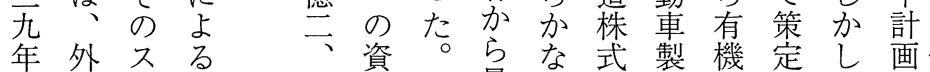
七国夕米 $\bigcirc$ 本日最よ会造的さなな 月企1国 $\bigcirc$ 金産大う社会総れ范当 時業卜世社合たら限に永 点とに論 万億満の、設を的と、の でのおの出州期鮎立設ない五方 確事い悪へは移待川咅ピう力針 定業て化増、駐を義机玄

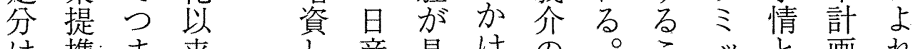

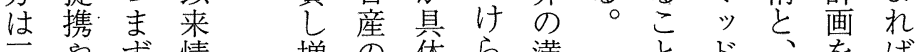

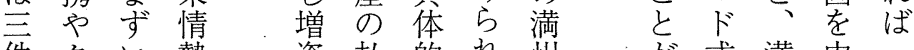

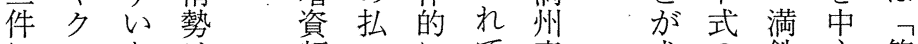
にレたは額いにて産求の鉄心第 すジの好の込ない業め総にと一 ぎッで転四みった開ら合かし期 す、卆五ての発的開わた 経 、にる、す、文、い構た発つ済

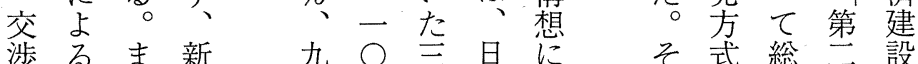

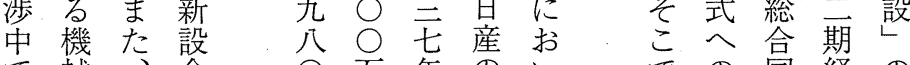
で械、会○方年のい学の国経の あ。外社方品擁て 転策済所

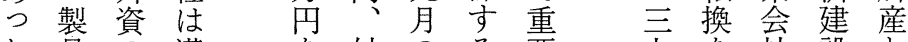
た品の満を外のる要卆を社設と

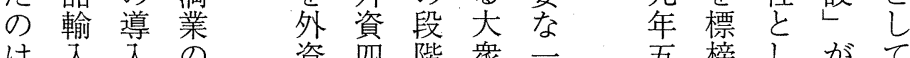

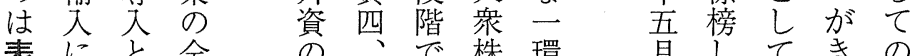

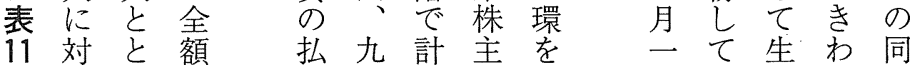

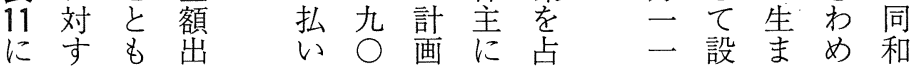


第27巻 第 2 号

表10 満業のクレジットによる機械・製品購入

\begin{tabular}{|c|c|c|c|c|c|c|}
\hline 国籍 & 相手方 & 品 名 & 買付額総額 & 現 金払 & 延 払 額 & 期 \\
\hline 米 & フォード & $\begin{array}{l}\text { 自 動 車 } \\
\text { 部 品 }\end{array}$ & $3,495,000 \$$ & - & $3,495,000 \$$ & $\begin{array}{l}1 / 5 \text { は } 2 \text { 年 } \\
4 / 5 \text { 年 }\end{array}$ \\
\hline 米 & G $\quad M$ & $\begin{array}{l}\text { 自動車 } \\
\text { 部分品 }\end{array}$ & $5,000,000$ 円 & 500,000 円 & $4,500,000$ 円 & 1 年 5 月 \\
\hline 独 & ベンッ & $\begin{array}{l}\text { デイ一ゼル } \\
\text { 車及部品 }\end{array}$ & 489,900 磅 & 48,990 磅 & 440,910 磅 & 11月 \\
\hline
\end{tabular}

(備考) 1939年 7 月現在確定分で、直接自動車部門のみ抽出した。

(出所)「外資問題経過報告」(康德 6 年 7 月 20 日) より作成。

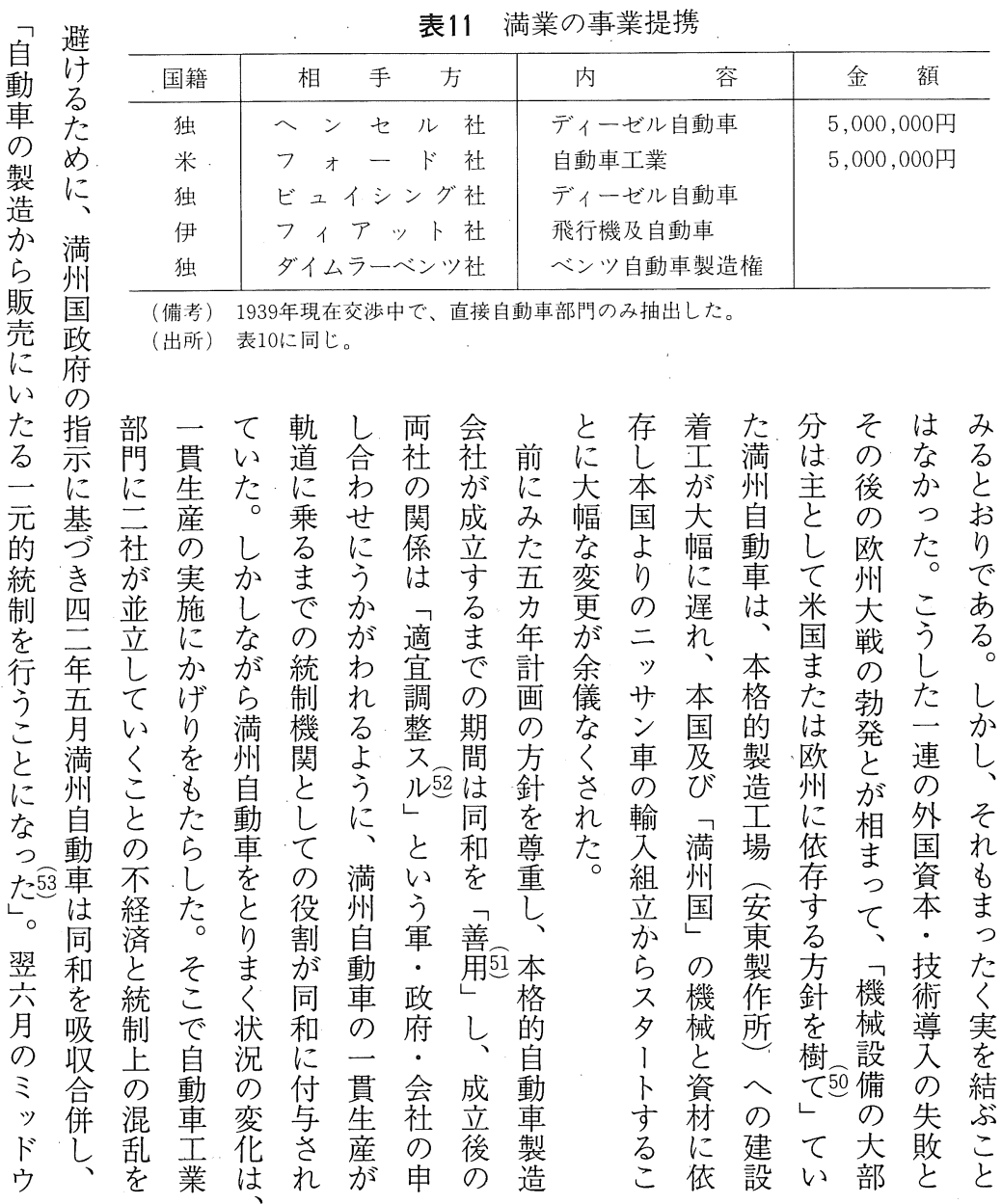


経 営史 学

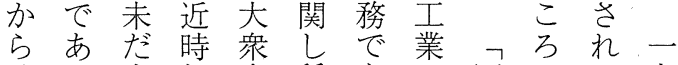
政る 完相車種あ当の国でた基防あ に加の寻製保。礎のる 同六 於 域規造護政を現。法年 てるに模事奨府為状その五 国に達に業励に方及こ意月 産最し大を在於所将で図、 自も居衆 確為て 謂来、文外 動有ら車立しは基に少る資 車力ずの市て成礎鑑しと系 工な更製る来に王み長こ会 業るに造こた茲業、くる社 に外数計とのにの自なはの 対国段画がで鑑—動る排 し会のを必あみと車が哌 適社努進要るるるし 業こ自と

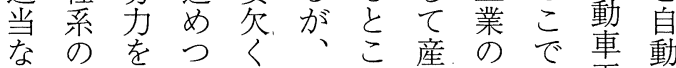
る自必、心殊 業確々軍 指動要あかにあ上立の業製 導車とるら最りには声法造 助工立を゙近十於最明要事 成業るのるの数て重を綱業 をがも\&こ国年も大紹しの 為存の—と防前最な介の許 す在で、っ上よ重るし閣可 にしあ二な友り要意て 議制 非、つあるる゙軍な義お決の ざ我てりりに経用るををこ定二 れ国、亡至済車地有うに点 ば大国認っ上を位方。際を 急衆産めたの中省方主 速車自らの必心占も て 貝 にの動るで要とむのの的 そ殆車、あにしるでに町と のど志のる基て も㐫田し 確全業で。きき斯のるる商た 立部亡亦然業での 期供てがに般発つな臣動 し給は、我に達てら䒁 難、し極之国最を之学声製 い居め等の も図が本明造 のるての現需り確工致 での幼計状要、立業门業 あ実稚画をのそはは法 る状なは見多の刻ままがし ○でる何るい確市た劣が 而あ状机に所立の二航公

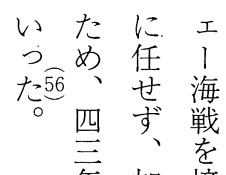

五年 加 境

月年

加安色

ら東を

開 製 深

始 作 め

さ 所 て

れのい

た一く

の 貫 な

が生 か

中産で、

制

定

車備 満

の ह 州

再 建 自

生設動

での 車

あ緒に

つには

た可つ本

以た五

後ばら

満加の

州 り $\mathrm{K}$

自亡 D

動 い, 部

車う品

の 状 の

事 況 輸

業で入

はあが

、つ ス

再た可

生 か プ

業かるて

急事 組

速態 立

に劣作

傾打業

斜開は

七 方 
フ 海 商極し交山芯な営、徒の自 自才支業的、涉場ちあ加業活とに, 確本動 動 1 店的姿商のをなるで法動こ多立側車 車ドはに勢工中迎み○专要のろ数はに工 製が、同を省でえに旦綱続での大於業 造中三国表事 $\mathrm{G}$ ○、産し行、企量て の

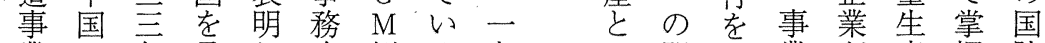
業へ年承し次則る九閣画業㤂産握防

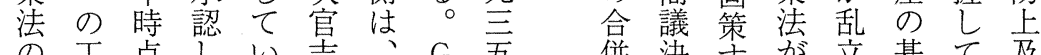

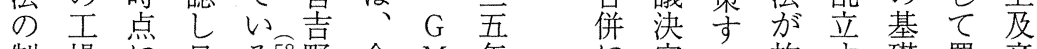
制場に日鸨野合 $\mathrm{M}$ 年に定る施す礎置産 定進お本。信併本六篮が行るるをく業

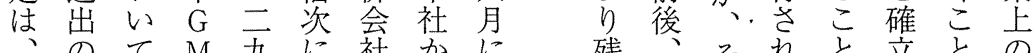

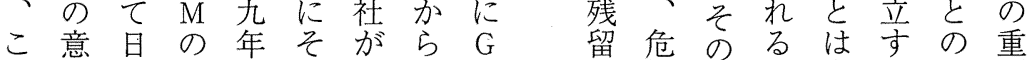
の向本販にの満派 $\mathrm{M}$ を機全と、之る必要 よをフ売上点州遣サ、意意少、をこ要性 う表オテ海に関さとイ 図識は日防となに な明りリにつ係れ、゙的を成本止にる鑑

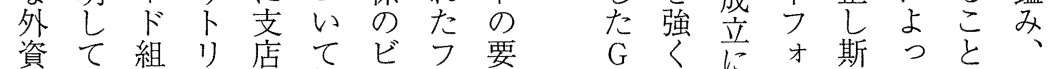

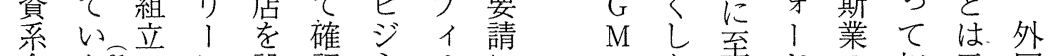

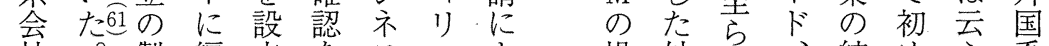
社。製編立を スッよ場外ず、統め交系 の 品入し求にプつ合資す、日制てをを会 大を吕てめつ不系四本安可俟社 陸市 取 せ 場り い, G と 他 日 ! へ 扱た $M$ \& $の$ 本 のつのはに民 GL 積てで、、族 $M$ た 極的古合資の旦 的戦古方哥云併本役 産 略々同に社差と動 展のじはの別亡車 開間 旦製を产立 を 至云本品受にの 封 $\overline{0}$ 八政の计日合 年年府中方産併 达ににの国か側交 めは開子市どと渉 る す 設 満場う精は

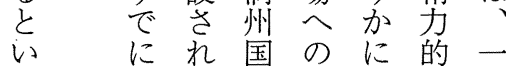
う、たた輸強に。

○フ承出い交月 こンオ認に関渉に

ま !に関心し大

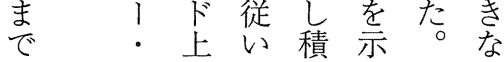

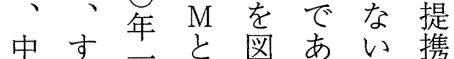
国で 市に思に必少こる 場我我日要ら 万加 をが势本が斯で如 強国国企あ業あき

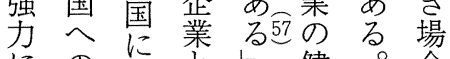
にの拈。健。合 意残けの全更に 識留る合なにあ 識戦众併学大る た略企や進衆て 動を括提。歩車も き積動携発を展目企 と的を極よ营標業 ろに停る 期との う展資守市支 と開た産るる配 ししたのが自権 てて 保為動は いい自全に車こ

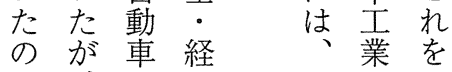




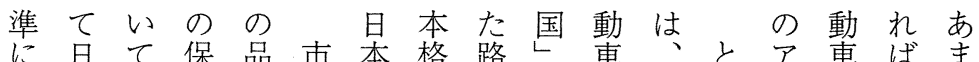
は本い護質場帝的線の莗 (1) こ ᄀフたは古国にに建要道ろ保严重 満才外、価外主道つ国し路で力有八視 州1 資当格資義路いになの三車さ年さ

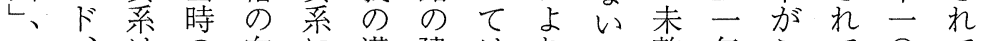

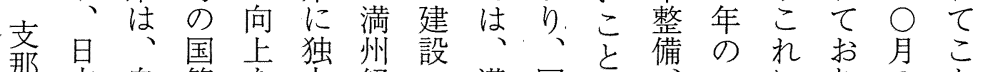

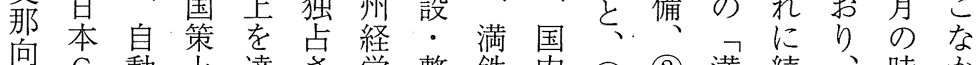

问 $\mathrm{G}$ 動 上 達 さ営整 鉄 内 (4) (2) 満続、時か の $\mathrm{M}$ 車す成製くは備が交治低州いう点つ 台そ製なした我自な゙国通安廉事てちでた

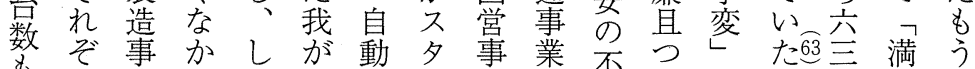

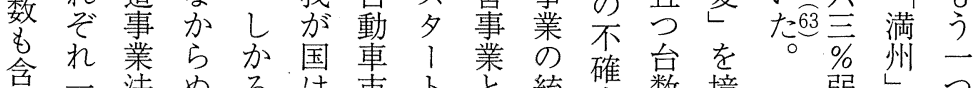

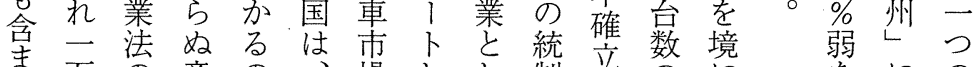
れ万の意の場しし、制立のに数の

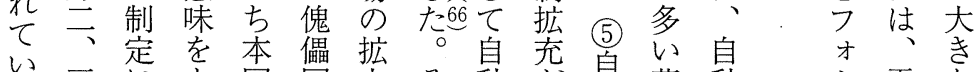

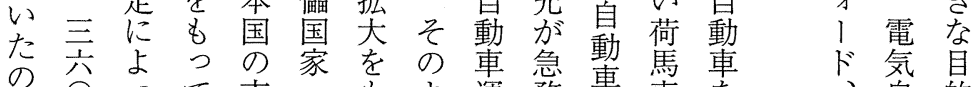

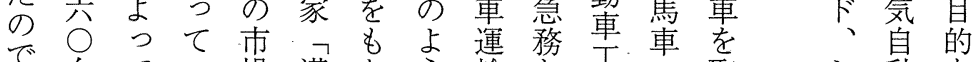
あ゙台てい場満た方輸と業の取势㗢を

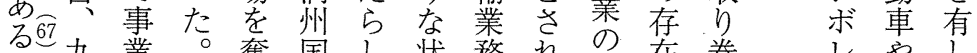
活横奪国し 状務れ不在巻 四動浜守につの担な在 (3) 環 がイい 七にやるそあ中当が等重境占! た

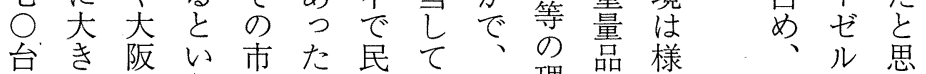
になのう場と間い三理に変絮車わ

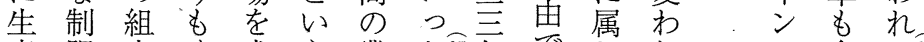

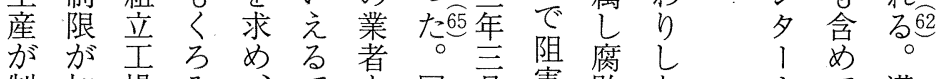
制加場み みでも同局害敗た ナて 満 限えをををあ次時加さ它を シ 一州

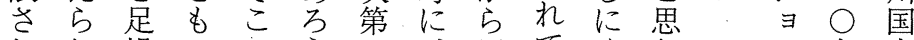
れれ場つでうに軍てくわ京 てたにての。登国事い、いれ種通 い。、い量場務的た羊特る 類部

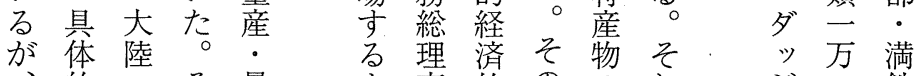

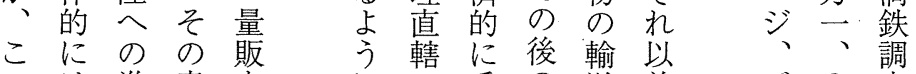
のは進意をにの重の送前にビ 、查 台、出味通国要事が自、会 部 数付をでじつ道々変必動瓜○の の則念満てて 局指と ず車州台調 算に頭州国いの定々しのの余査

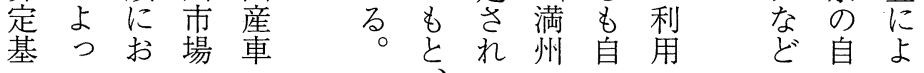




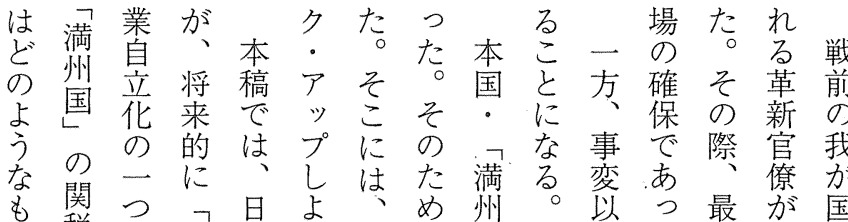
の税の満早方産に州な降た最抱に で政ポ州とと業事を加日。のい㧍

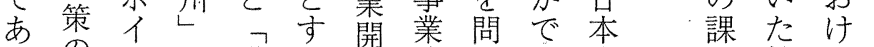
つのンの満る発法わ主題統るわ た推卜市州政の等にず息国等自り

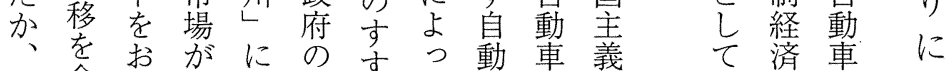

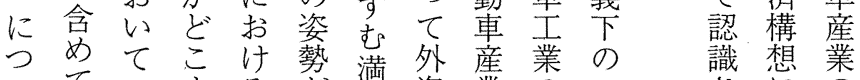
いていまるが洲資業のっコさにの て早たで自う市系の育満れよ育 史本占成動加場会国成州てっ成

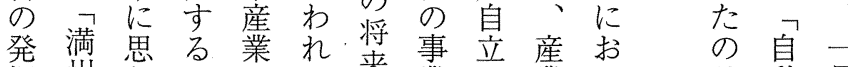

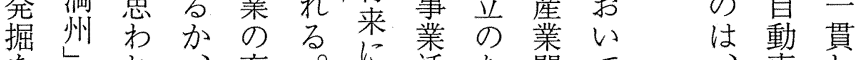

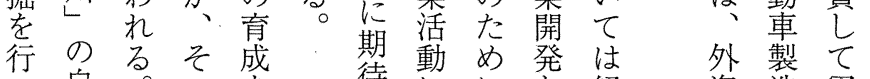
つ自。のを待ににと経資造軍 て動し市め。寄制は軍済系事部 実車た場ぐ・寄限、事建会業の

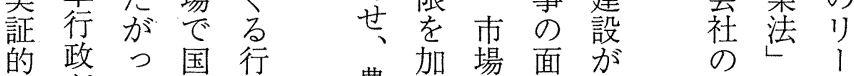
にがて産政豊えの㔔排と多 解ど、重の田な確ら寻哌い! 明こ残が動な が保急め方う シ すまさどき、どらに務ら具ッ

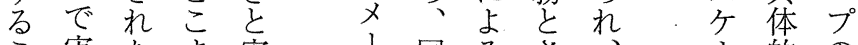
こ実たま実同るささ的の と質課で施吕時品れ軍儿なも で的題シ状 lに質た需・尔と あにのエ況に大少要メたに ろ連うアによ陸向で業りちす

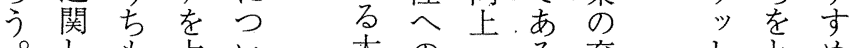

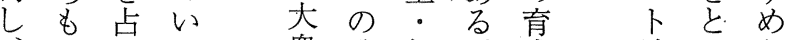
つめて衆戦価。成追っら 満とら考車略格は求てれ 州もれ察市展の次に最、 市重るを場開低第必終岸 場要かす委年に要的信 のなにす開もが重なに界 位問自め拓封必要国表に 置題動て它要視産現代 付は車きだ込でささ車さ表 


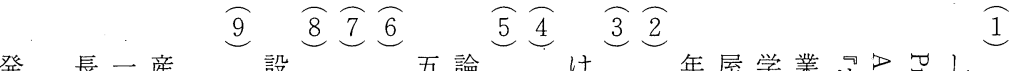

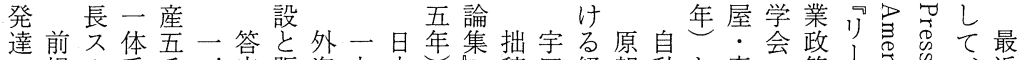
三揭儿系干・审貶資九本、稿田経朗動お森策！号。近

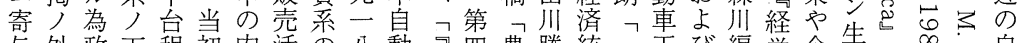
与外政下程初内活の八動渾四豊勝統一エび編営企生草心》自

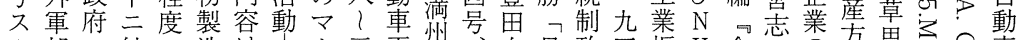

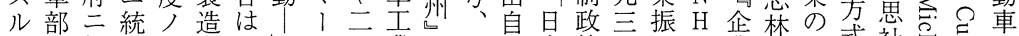

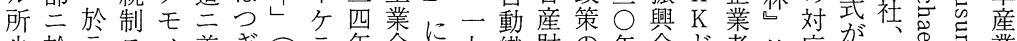

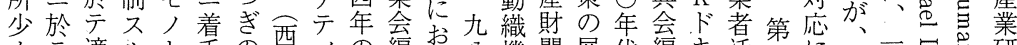

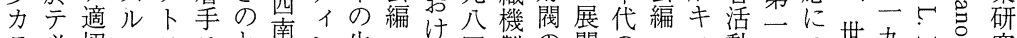

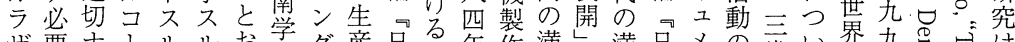

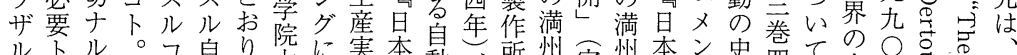

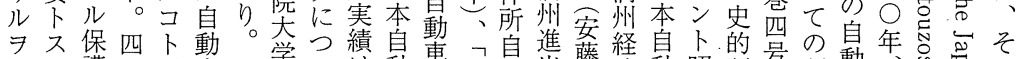

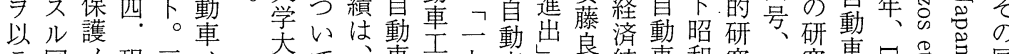
テ国分現三人学て、車業九車良統車和究一究車 依産施存一種 然, 設自 製類 之規 7 動造八 格講車方貨 存高 ジ工法物 置キ尚場八自 存国及分動 ル物産其業車 ヨ自自兵 及 必動動他依 乗 要車車,ル合 号草工コ自 又至使場卜動 可特用, 卜車 シ殊奨設シ 自励備各目 商動二経部標 工車付験分卡 省, 等三ス 工民公与付ル 務間特可精 コ 局保別成密卜 編存ナ梨ナー 自対考古角規二 動 慮儿格製 車ルタコヨ造 業奨払长定規 確公吉五筫少 立調接。本憅少

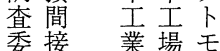
筫三人会 会二 健 ビ後 経般全ソ五 過自ナノ年 概動儿関目 要車発係三 一業 達志場於

九助 $\ni$ 年

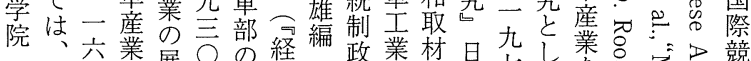

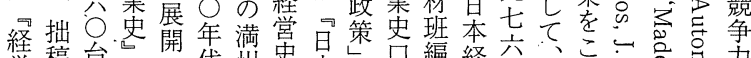

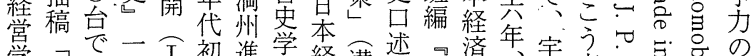

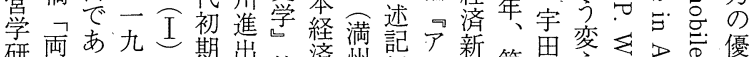

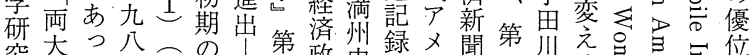

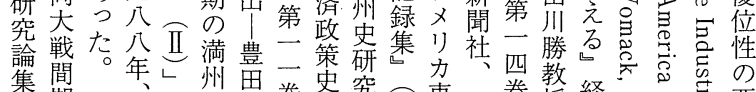

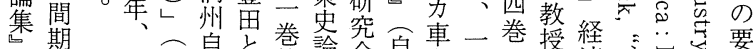

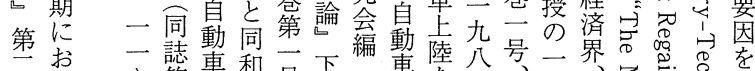

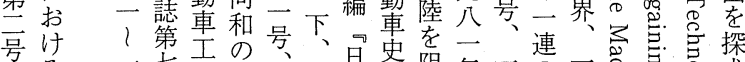

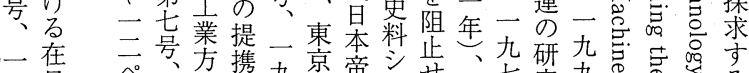

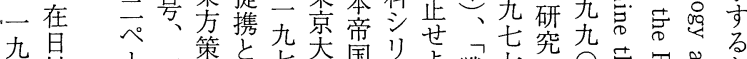

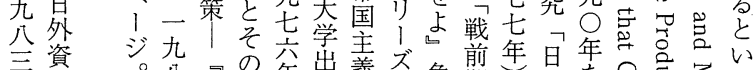
年系。八淦破年出義第角期、産を今前尔

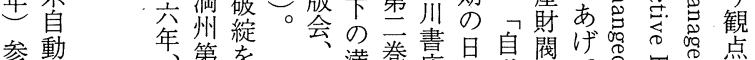

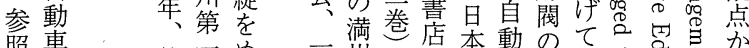

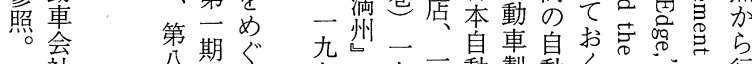
社号経う: 七御九甥製動く芝。行

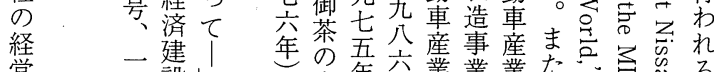
営萿設冰年年業業業だ恕る

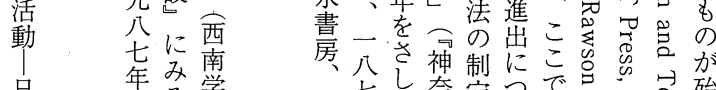
早年学院一七七奈定つで浬口包殆

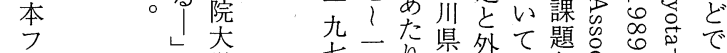

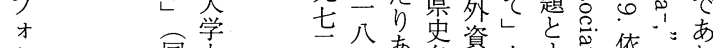

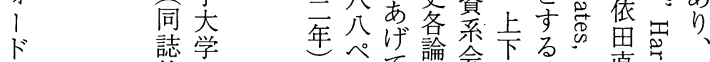
第院、、て編社戦它直代

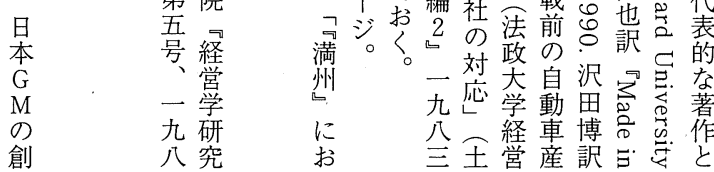




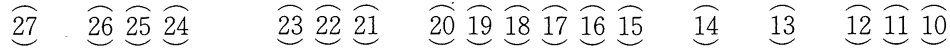
京小課 $、$ 満関吾で部あ満っ策自伊 $\mathrm{N}$ 同同伊詳日無伊商三伊同三 斯磯経自鉄東主る満鉄満と動藤 $\mathrm{H}$ 右右藤し産哕藤省西藤右年 電国済動、軍查。州経州卜車前 $\mathrm{K}$ 稿稿前いと、前よ年久書 気昭調車前特产十に済第ヨ製掲、揭。 $\mathrm{G}$ 一揭り言雄

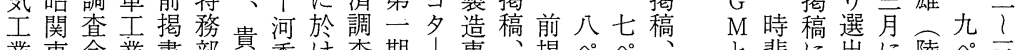

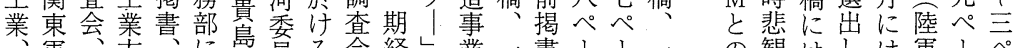

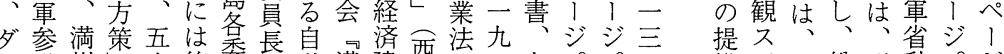

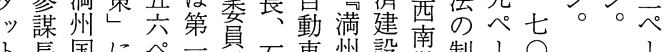

卜長国にペー買石車州設南制10

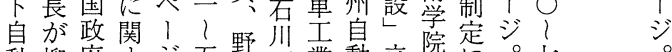

動柳府要ジ五野副業動立管に。七

車川のる。の鉄委対車案学吉四

平財連委鉄䆩策工学け的 引助務合筫道長案業仕学て

用陸部研

者軍実究 会坦方組学の浣

, 宛業会

に部件

与企交関

又家通東

更泉部軍

三満よ議

他州り 事

進総 録

資出勢

本に三同

会場武に策み院行

打長部関衣経政

か内部等章賞経政

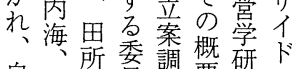

甥畐山会查に毭論動

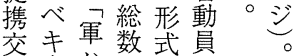

渉事分は決課

乷象国染定速

今内委自

い現界界名筫動

て出界。古重

は多㤫任草

岸宇ル者命業

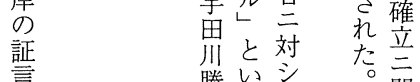

車、崎会類い集き

勝方 委関

白記国委不

産述家は経

業泉奥件第て第卜

に調村経交は編第当

查第済第原号多

て員第調四原、の

毛以名書

加て加曋

相質出五

相し席べ

当ただ

力に

は示查巻朗一企

磁加的

閥あ見

閥あ見整過
自。地 備一

ル対磁

会? 究

業主議一元八行

主淨九九尣行

鉱、釷录豆至年

次会

㠈

佐同吾年を倸

関 藤右苂代参わ

書一渾照り

統 第七七畫一満照に

満 官

州は特定

設 既 務

ケ存部

夕第

部ぺ経い

主1 济

查泟重制は、

中同景策㑕

島委大学

第会経に詳戦

四の済詳前

部出学しの

意 委

委

部席部い。

ナ而

ル島

会

查者所

、查蔵

岡の

田と

第り

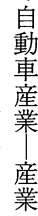

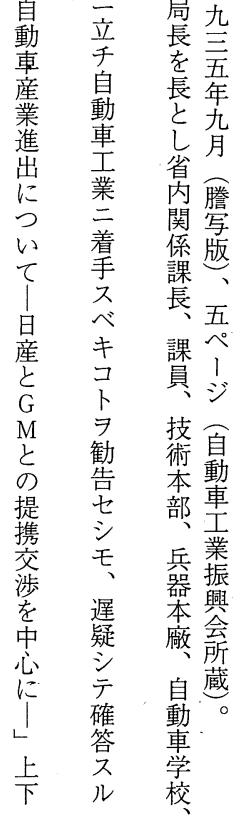




$$
\overparen{40} \overparen{39} \overparen{38} \overparen{37} \quad \widehat{36} \quad \widehat{35} \quad \widehat{34} \widehat{33} \quad \widehat{32} \widehat{31} \widehat{30} \widehat{29} \widehat{28}
$$

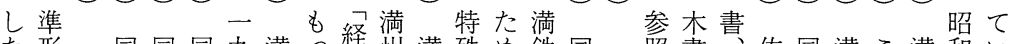
た形、同同同九満つ経州満殊め鉄同っ照書佐同満こ満和い 式満右右右八鉄て調国鉄会資々和日。店一名鉄の鉄八る 維車州書書書 ○調い調よの社本政の満 持加事、年査た查り職制の府資自 補軍変三五一。部年委の制度蓄の本動

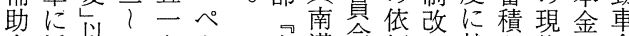
金採降一! l自満会頼正就加物亲会 は用降四七ジ。動州のにに主少出社 いさ軍ぺ六。車鉄主対よょな資

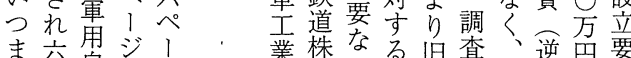
で輪自。動関式各回経報日産は綱 継車憅。係会夕答济告本生は案 続は車

直颠

た接助

か軍法

定の保

藮護

で注證

なに対

い⿺辶象

標製は、

準造一

車さ。

のれ五

生るト

産こン

はと以

に上

三なの

引る六

年。輪

度車

克て そ

西補の

年助応

度法用

にに車

そよに

れる限

ぞ製ら

れ造れ

五購 る

○買と

台補に

資社只調第本の満

料、フ ᄀ於查二国結州に

南と直二会国関

満洲しけ会七資加政卞

州鉄他量産号本中府可

・道の拲部一頼的が合

五株諸箇部九管位 $\overrightarrow{0}$

箇式機所金四ざ置方究

年会関と金在方古会

計社をしに年を占占件

画第援て吸云得め現件

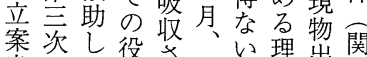

案次し役要つ割—事出瓷

類年つ割れ三事由資軍

第史満有たへ加つ、議

綟下蒙しま落い淦事

編下及及关在て鉄録

第、北委経。しは方

七一支䆩叠たは満

巻九の貝済

一鏟は調查国品前

九年.開社委で前召前

三三発各会

年主経係新

一九済部設

五一展のさ

人方筒れ

七四策乴

七三亥樹長経

1 ペ立委調

ジ! 嘱查

七金る

○はた

○実が

台質

の的商

害に工

績消省

湆参冏

龍。畫れ立

幥京た案

あの円揭

る満日

以州本五

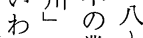

れが業!

る半者交第点旦

九木書、間、年

二七隆、前の前二満

九爾六揭経揭四州 交年、近言畫緯畫冊州自

年小代六九つ九内動

、小杂七い主其車

鈴英星1一は九八関

木夫制棌○六、 ス

隆子論。公原へ防儿

史五正ぺ 徫件

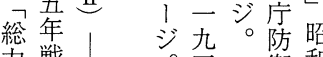

妿戦旦济杂衛和

戰争本官研七

制植了年究年

植地念少満畫月

民公洲館八

地同論経啠日

支上ᄂ

配書

石制軍

満日并

州本治

の フ 海

場 三野

合无福

| 公寿豆謀

入 形中

日成 村

本過政

史程則

研の

究問近

横建社ぺ-○経

浜的加 ! 一歴済

正的兰。号史史

蔵陸

金半二

銀植 ○

行民万

調 地円

查経を

部済出

全。㣗産関

复”役業し

港で資

刻割部軍州った

を滅標

版をは及

国た

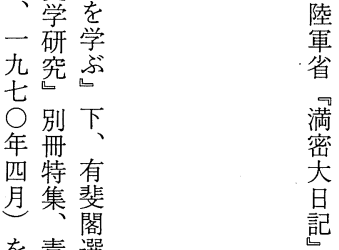




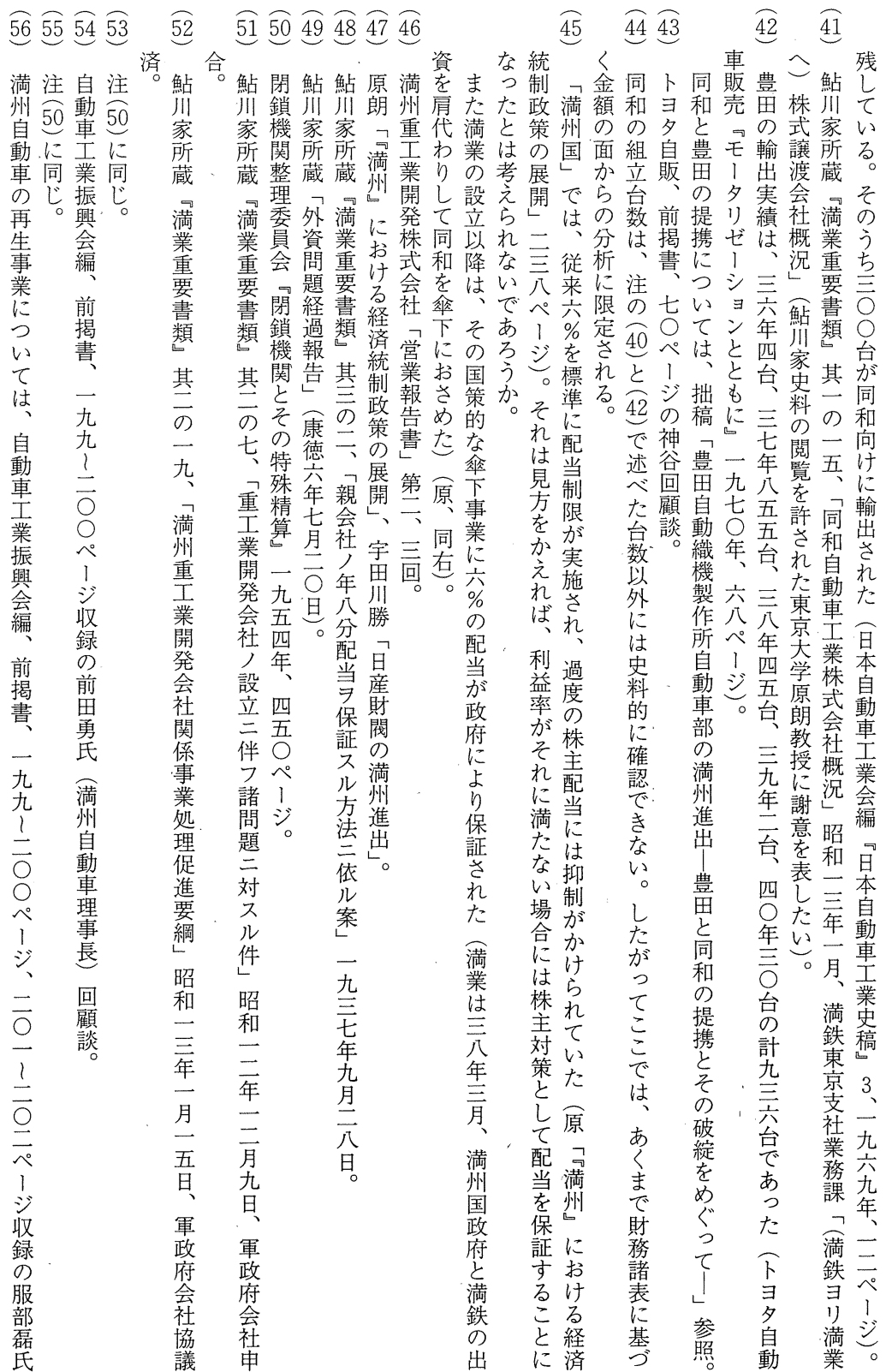




$$
\overparen{67} \overparen{66} \overparen{65} \overparen{64} \overparen{63} \quad \overparen{62} \overparen{61} \overparen{60} \underset{59}{50} \overparen{58}
$$

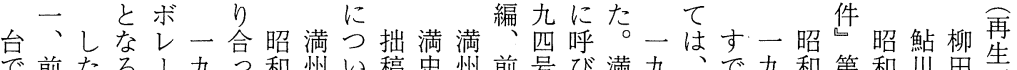
で前たる1九つ和州い稿史州前号び満九、で和第和川思生

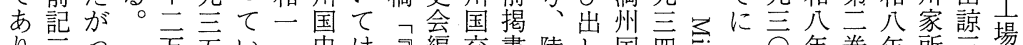

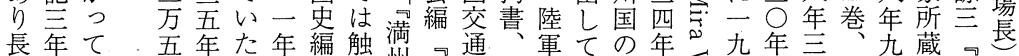

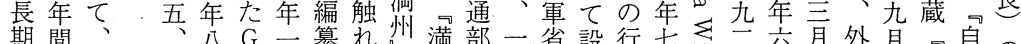

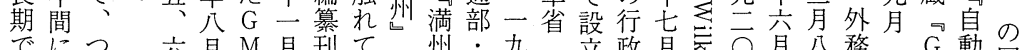

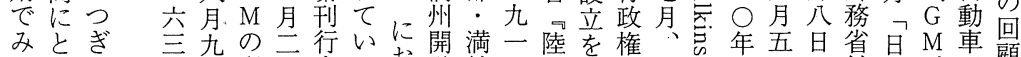

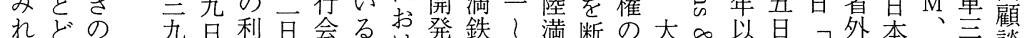
ばまよ台の益鮎編。け四調一密念及連珞付日交セ草談

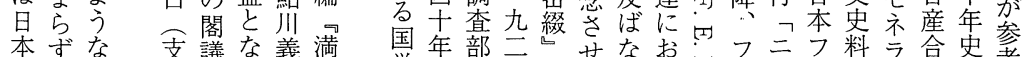

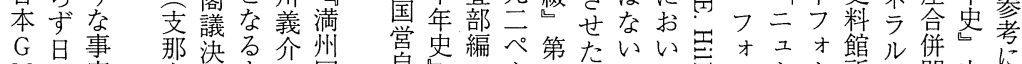
$\mathrm{M}$ 本実、向定よよ国 の $\mathrm{G}$ け以うり史 生鏟設㖛前前送金各 架立て 言年ら義論 多の不台間れ照 い二公を告だ満 七平含生㐫商蒙 年の吉産の而 是定で省胞 三正を績あ賁援 年訴準すこ局会 半元学なこ王一 期いてわ攵課九 穾。算フそ長七 実定才内宛年

は、れド容書

シ 枯方簡四

ボ 以立てこ吾

七 降一䇢書簡。

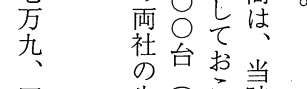

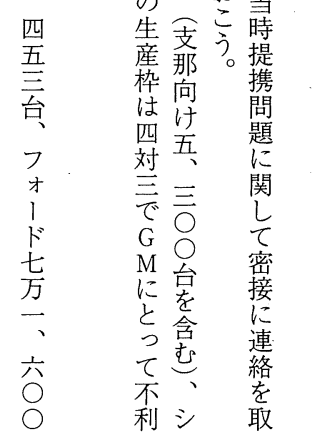
赏史編へ第たいい忽オユオ館ル併心考 動上満ジ三と東数っドヨド蔵壬題水な

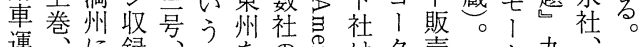
運に録、至をの怘は夕売多九

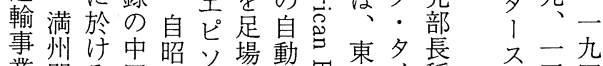
業開る田和〉に喠嵒尔イ稲株三四

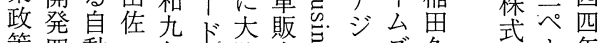
策四動二年\&陸売怘アズ久会 ! 年

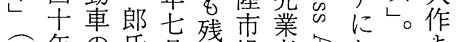

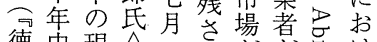
德史現入一れがが各け 山刊勢一七七侵共吕る 大行調九日て害同气拠 学会査至るさ出々点 総——三向年資怘

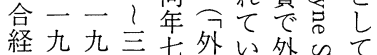
済六咅亲国〈車导中 研四旮年三自の帛国 究年年関六動を輸气に 所、、東昌車恐入灵対 紀六五軍、会犯組总造 第ぺ洨部衛設関会出出

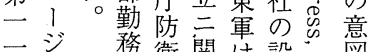
一涪務衛関は設”図

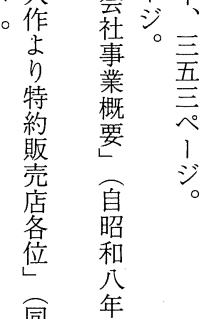
号、研 ス、立 回究儿発㫗吕有外 一顧所件起請的 L 国 九談図人を自官它 八参書昭代な吕い動 九照館和表し、た 年啠蔵年福関思 に七昌東わ 拈息公序标 右 月

省 録 外

動

車 嶪 て車日社よ。品 そ業陸を長認れ学职 の振満特可に関 経興第務さつ係 


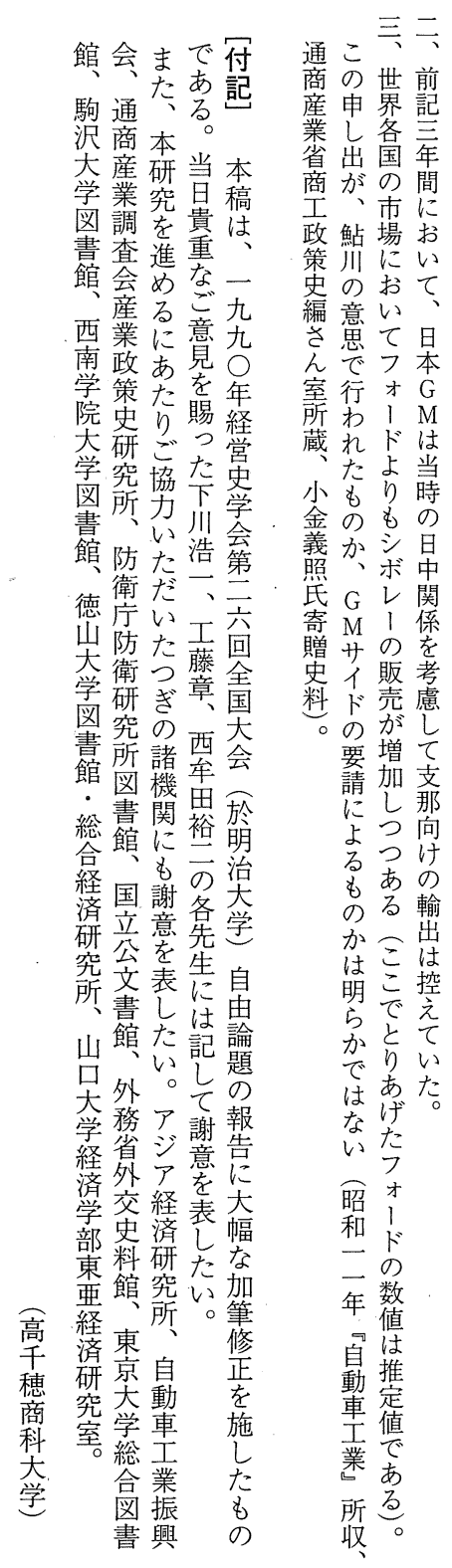




\title{
THE ROLE OF MANCHURIAN MARKET FOR THE JAPANESE AUTOMOBILE INDUSTRY IN PRE-WAR
}

\author{
Masachika Shinomiya \\ Takachiho College of Commerce
}

The Japanese automobile market in pre-war had been dominated by Japan Ford and Japan GM. So, the aim of automobile industrial policy was to protect the market against foreign companies, to foster domestic manufacturers and finally to control the industry. Specially the army had intended to eliminate the foreign companies after the 1931 Manchurian incident.

After the army occupied Manchuria in 1931, heavy-industrialization policy had been executed by Japan there. Aircraft and automobile industries as the war industries had been thought important. Army had intended to protect the automobile market and to foster the automobile industry in Manchuria.

The goal of the 1936 Automobile Manufacturing Business Law was to permit the automobile manufacturing business and to eliminate the foreign companies. Furthermore, the law was to protect the automobile market against foreign companies in Manchuria. Substantially it had been prohibited for foreign companies to make inroads into Manchurian market.

In fostering the automobile industry in Japan and Manchuria, Manchurian market was very important in these two points :

1. As the market of Japanese automobiles.

2. In fostering the auto business in Manchuria.

Therefore in order to foster the automobile industry, the operation of foreign companies in Manchuria had never been permitted. 